\title{
ÆUSGS
}

science for a changing world

In cooperation with the National Park Service, Zion National Park

\section{Ecological Investigations of the Federally Endangered Shivwits Milk-Vetch (Astragalus ampullarioides) - 2006 Annual Report}

By Mark E. Miller ${ }^{1}$, Rebecca K. Mann ${ }^{1}$, Harland Goldstein ${ }^{2}$, and James D. Yount ${ }^{2}$

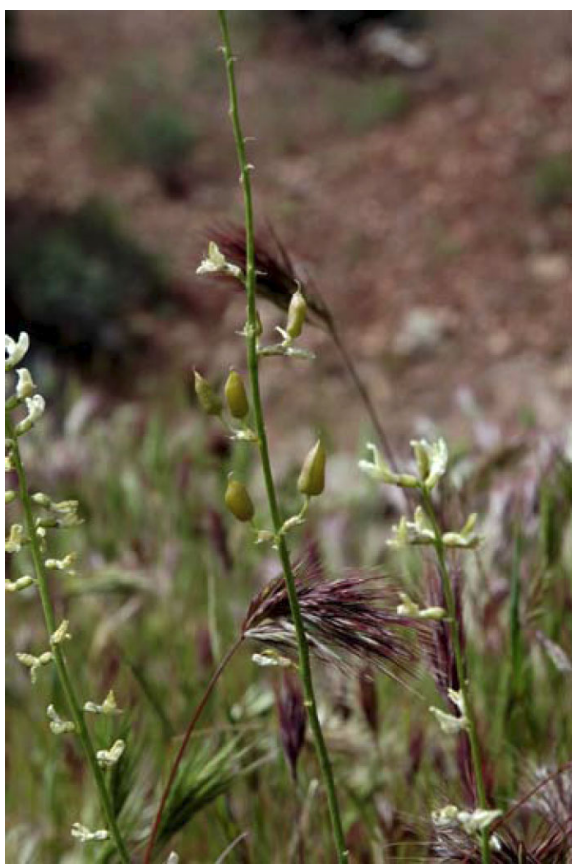

Open-File Report 2007-1050

2007

U.S. Department of the Interior

U.S. Geological Survey

${ }^{1}$ Southwest Biological Science Center, Grand Staircase-Escalante National Monument, 190 E. Center St., Kanab, UT 84741

${ }^{2}$ Earth Surface Processes Team, Denver Federal Center, MS 980, Box 25046, Denver, CO 80225 


\title{
U.S. Department of the Interior DIRK KEMPTHORNE, Secretary
}

\author{
U.S. Geological Survey \\ Mark D. Myers, Director
}

U.S. Geological Survey, Reston, Virginia 2007

For product and ordering information:

World Wide Web: http://www.usgs.gov/pubprod

Telephone: 1-888-ASK-USGS

For more information on the USGS - the Federal source for science about the Earth, its natural and living resources, natural hazards, and the environment:

World Wide Web: http://www.usgs.gov

Telephone: 1-888-ASK-USGS

Suggested citation:

Miller, Mark, Mann, Rebecca K., Goldstein, Harland, and Yount, James D., 2007, Ecological investigations of the federally endangered Shivwits milk-vetch (Astragalus ampullarioides) - 2006 annual report: U.S. Geological Survey Open-File Report 20071050 [available on the World Wide Web at URL http://pubs.usgs.gov/of/2007/1050/ ].

Cover photograph: Shivwits milk-vetch (Astragalus ampullarioides) by Dr. Renee Van Buren

Any use of trade, product, or firm names is for descriptive purposes only and does not imply endorsement by the U.S. Government. 


\section{Contents}

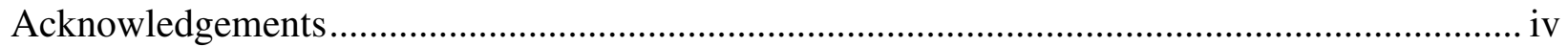

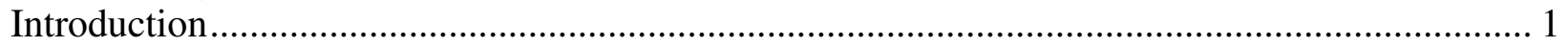

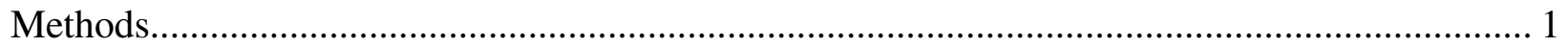

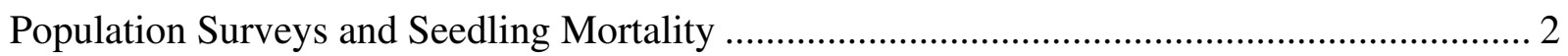

Reproductive Output and Effects of Native Vertebrate Herbivory ……………………............. 2

Descriptive Soil-Vegetation Sampling ………………......................................................... 2

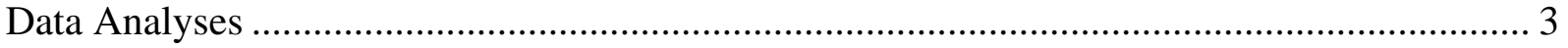

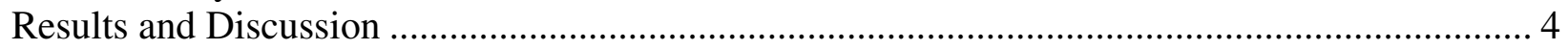

Population Surveys and Seedling Mortality …………........................................................ 4

Reproductive Output and Effects of Native Vertebrate Herbivory …………………................ 5

Descriptive Soil-Vegetation Sampling ……………………....................................................... 6

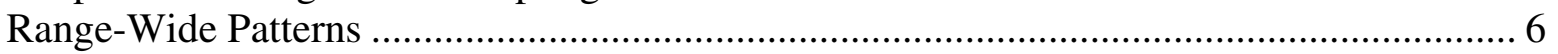

Site-Level Patterns .................................................................................................... 13

On-Going Work and Future Plans ........................................................................................ 18

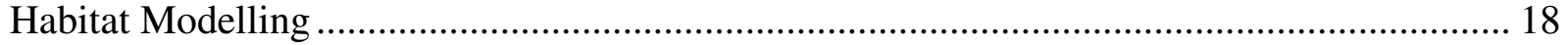

Experimental Studies of Red Brome Effects on Biological Soil Properties and Milk-Vetch

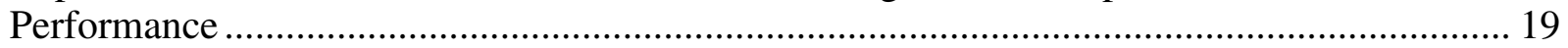

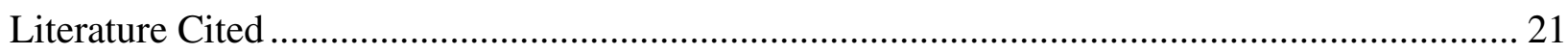

Appendix A - Map of Plot Locations …………………………………………………... 23

Appendix B - Graphs for Herbivory Experiment........................................................................24

Appendix C - Plot-Level Quadrat data....................................................................................26

Appendix D - All Soil-Vegetation Plots in Relation to Soil Texture Classes................................33 


\section{Acknowledgements}

We thank Becca Lieberg and Cheryl Decker of Zion National Park for their enthusiastic and skilled assistance with numerous aspects of this research. Denise Louie, Jeff Bradybaugh (both formerly of Zion National Park), and Heather Barnes (U.S. Fish and Wildlife Service) were instrumental in developing the vision for the project. Nancy Johnson, Bala Chaudhary, and Matthew Bowker of Northern Arizona University have provided key guidance and support for our on-going investigations of mycorrhizal relations of the Shivwits milk-vetch. Renee Van Buren (Utah Valley State College) and Bob Douglas (Bureau of Land Management) have been important sources of background information on milk-vetch ecology and habitat characteristics. We thank Glenn Rogers (Chairman, Shivwits Band of the Paiute Tribe) for granting us permission to work on Tribal lands. Walter Fertig (Moenave Botanical Consulting) assisted with plant identifications, and has been a key advisor in our on-going habitat-modeling work. Review comments from Richard Reynolds, Jayne Belnap, Charles Powell, and Mark Sogge improved the quality of the report. 


\section{Introduction}

Astragalus ampullarioides (Welsh) Welsh, the Shivwits milk-vetch, is an herbaceous perennial legume that was listed as federally endangered in September 2001 (U.S. Fish and Wildlife Service 2001). Known populations of this edaphic endemic species are restricted to Washington County, Utah, with the majority of occurrences found on gently sloping outcrops of the Triassic Petrified Forest Member of the Chinle Formation at the edge of the Mojave Desert. At the time of listing in 2001, surveys estimated a total of 1000 individuals for the species. In April-May 2006, surveys estimated approximately 4205 individuals distributed among 6 populations (U.S. Fish and Wildlife Service 2006). Of the total number of individuals estimated in spring 2006, over 75 percent were distributed among three subpopulations in Zion National Park and approximately 60 percent occurred at a single 0.3-ha site in the Park. In addition to small population sizes and limited geographic distributions, the species is threatened to varying degrees by urbanization, livestock grazing, off-road vehicle use, and invasive exotic plants (U.S. Fish and Wildlife Service 2001, 2006; Van Buren and Harper 2003).

In April 2006, the U.S. Geological Survey (USGS) initiated ecological investigations of the Shivwits milk-vetch to support conservation management and recovery of the species by the National Park Service (NPS; Zion National Park), the U.S. Fish and Wildlife Service (USFWS), the Bureau of Land Management (BLM), the Shivwits Band of the Paiute Tribe, and other cooperators such as The Nature Conservancy of Utah (TNC). To date, funding for this research has been provided by the Southwest Biological Science Center of the USGS Biological Resources Discipline, the USGS-NPS Park-Oriented Biological Support Project, and the Earth Surface Dynamics Program of the USGS Geologic Discipline. Additional logistical support has been provided by the Bureau of Land Management, Grand Staircase-Escalante National Monument.

General objectives of this research are (1) to develop a better understanding of species-environment relations to support habitat modelling, future surveys for additional recovery populations, and potential efforts to establish new recovery populations; and (2) to evaluate effects of invasive exotic plants on habitat conditions and measures of milk-vetch performance. Specific objectives are to:

1. Describe the distribution and abundance of milk-vetch populations and associated invasive exotic plant species within and outside of Zion National Park (Zion NP) in relation to geologic / geomorphic setting, soil properties, and plant community composition.

2. In a field setting in Zion NP, conduct experiments to evaluate effects of invasive exotic plants on reproductive output and seedling establishment of $A$. ampullarioides across a gradient of exotic species biomass.

3. Conduct greenhouse studies and analyze soils to evaluate effects of invasive exotic plants on soil biological properties (including mycorrhizal inocculation potential) that affect cycling and plant uptake of essential mineral nutrients.

4. Based on environmental characteristics of known population locations, use Geographic Information System (GIS) tools to prepare a predictive habitat model that can be used to guide future surveys and efforts to evaluate sites for reintroduction efforts.

This report describes 2006 progress and future plans for achieving these four objectives.

\section{Methods}

Work during 2006 focused on conducting population surveys and estimating seedling mortality, experimentally evaluating effects of native vertebrate herbivory on milk-vetch reproductive output at a site in Zion NP, sampling to describe soil-vegetation relations at five population locations, and 
initiating a field experiment to examine effects of the invasive exotic grass red brome (Bromus rubens) on soil properties and milk-vetch performance. The work described in this report followed techniques approved by U.S. Fish and Wildlife Service Endangered Species Permit \# TE130417-0 and National Park Service Scientific Research and Collecting Permit \# ZION-2006-SCI-0024.

\section{Population Surveys and Seedling Mortality}

During the April-May 2006 period, population surveys were conducted at seven study sites associated with five of the six known milk-vetch populations. Surveys were conducted opportunistically while describing geologic settings of known populations and preparing for descriptive soil-vegetation sampling. Surveys focused on areas with known milk-vetch occurrences and generally did not involve searches for new populations or subpopulations. Individual milk-vetch plants were classified and enumerated as seedlings (cotyledons evident; single, 1-mm diameter stems) or established plants (evidence of previous years' growth; stems greater than 1-mm in diameter; occasionally with multiple stems; no cotyledons). At one site (Zion Hilltop), 160 seedlings distributed among 12 plots were marked with plastic tags and tracked during a 1-month period (20 April - 23 May) to estimate seedling mortality. Plots measured 1-2 m in diameter and had 10-30 marked seedlings apiece, depending on natural levels of abundance. Fractional cover of litter, rocks, and plants were estimated in each plot to assess whether patterns of seedling mortality were related to variations in these variables.

\section{Reproductive Output and Effects of Native Vertebrate Herbivory}

Shivwits milk-vetch is noted for its high degree of palatability, with its inflorescences commonly consumed by wildlife (Welsh et al. 2003). To reduce effects of herbivory on fruit production and thus increase our ability to collect seed required for subsequent field and greenhouse experiments (Objectives 2 and 3, above), at the Zion Hilltop site we enclosed 62 established milk-vetch plants within circular herbivore-exclusion cages on 20 April. Cages measured 40-cm in diameter and were $60-\mathrm{cm}$ tall, with sides and lids constructed from wire hardware cloth with 0.5 -in mesh. To quantitatively assess effects of herbivory on reproductive output, we paired each caged plant with a nearby uncaged plant of similar size and vigor. After fruiting but before plant senescence in late May, we measured canopy dimensions and counted reproductive shoots and fruits on caged and uncaged plants.

\section{Descriptive Soil-Vegetation Sampling}

A major objective of the spring 2006 field season was to describe range-wide and site-level variations in the relative abundance of Shivwits milk-vetch and associated invasive exotic plants in relation to geologic substrate, geomorphic setting, and soil physical and chemical properties. In April 2006, we visited the six known populations of Shivwits milk-vetch (see Figure A1) and confirmed geologic substrates associated with milk-vetch occurrences on the basis of published geologic maps (Hintze and Hammond 1994, Willis et al. 2002, Biek 2003) and field observations of lithology and stratigraphy.

Soil-vegetation sampling was conducted at sites characterized by relatively distinct spatial patterns in the relative distribution and abundance of Shivwits milk-vetch and invasive exotic plants (Zion, Pahcoon, Coral Canyon, and Harrisburg Bench populations), and at the Shivwits Paiute Reservation where the milk-vetch population was found to occur on two separate geologic units. At each site, soil, vegetation, and ground cover were sampled in plots subjectively located to characterize patterns in plant-environment relations. The size and configuration of soil-vegetation plots varied depending on spatial properties of the soil-vegetation patch being sampled, but each plot generally consisted of 12-20 square, $1-\mathrm{m}^{2}$ quadrats placed at random intervals along 2-5 
transects. Transects varied in length from 8 to $30 \mathrm{~m}$ long, and sampled soil-vegetation patches varied in size from 65 to $150 \mathrm{~m}^{2}$. Within each quadrat, we recorded occurrences of vascular plant species within a series of square nested-frequency quadrats $\left(0.01,0.1,0.5\right.$, and $\left.1.0 \mathrm{~m}^{2}\right)$ and estimated fractional cover of plants, standing dead brome grass, and ground cover (litter, woody debris, rocks by size class, and biological soil crusts) to the nearest 1 percent in the $1-\mathrm{m}^{2}$ quadrat. In this report (Table 3 and Appendix C), we only summarize frequency results for $1-\mathrm{m}^{2}$ quadrats.

Within each plot, several types of soil samples were collected for laboratory analyses. Composite soil samples were collected from 0-2 and 2-10 cm depth, with each composite consisting of 8-10 subsamples collected with a hand trowel. Near the center of each plot, we used a soil auger (7.5 $\mathrm{cm}$ diameter) to collect an additional set of samples from 0-10, 10-20, and 20-30 cm depth. Finally, we used a hammer core sampler (4.7-cm diameter, 10-cm depth) to collect 2-3 intact replicate samples for laboratory determination of bulk density and volumetric water content. In the lab, composite and auger samples were air dried, weighed, and sieved to separate and determine the relative proportion by mass of rock fragments $(>2 \mathrm{~mm})$ and fine earth $(<2 \mathrm{~mm})$. Splits from the composite samples were sent to the Plant and Soil Analysis Laboratory at Brigham Young University for determination of $\mathrm{pH}$, cation exchange capacity, organic matter content, and nutrient availability (total Kjeldahl $\mathrm{N}$; exchangeable $\mathrm{Ca}, \mathrm{Mg}, \mathrm{K}$, and $\mathrm{Na}$ extracted with $\mathrm{NH}_{4}-\mathrm{OAC}$ at $\mathrm{pH}$ 8.5; $\mathrm{NaHCO}_{3}$-extractable $\mathrm{K}$ and P; and DTPA-extractable $\mathrm{Mn}, \mathrm{Cu}, \mathrm{Zn}$, and Fe). Splits from composite and auger samples were sent to USGS laboratories in Denver for particle size analysis using a Malvern laser particle sizer, and for determination of gypsum and carbonate content. Composite splits also will be analyzed in Denver for total elemental content following a two-acid digestion and determination by inductively coupled plasma atomic-emission spectroscopy (ICPAES). Most chemical analyses have not yet been completed, thus laboratory results presented below are restricted to data from the texture (particle size) analyses. Particle-size ranges for reported sand $(63-2000 \mathrm{~m})$, silt $(3.9-63 \mathrm{~m})$, and clay $(<3.9 \mathrm{~m})$ fractions follow the Modified Wentworth scale (Ingram 1982).

Slope, aspect, geographic coordinates, and elevation also were measured for each soil-vegetation plot. Slope and aspect were measured in the field with a hand-held magnetic compass. Geographic coordinates were determined with a GPS (geographic positioning system) unit. Plot elevations were determined in the office by extracting data from a 10-m digital elevation model (DEM) using plot coordinates in a Geographic Information System (GIS). Data for slope, aspect, and latitude were used to calculate a topographic heat-load index for each plot following methods of McCune and Keon (2002).

\section{Data Analyses}

Effects of herbivory on milk-vetch performance measures were evaluated with the nonparametric Wilcoxon Matched Pairs test using Statistica v. 6.1 on a Windows platform (StatSoft, Inc. 2004). $\mathrm{P}$-values less than 0.05 were considered statistically significant. Two multivariate ordination techniques were used to examine variability in environmental measures and plant community composition among the 20 soil-vegetation plots. Principal components analysis (PCA; McCune and Grace 2002) was used to evaluate among-plot variability in environmental measures using the Factor Analysis module of Statistica v. 6.1 (StatSoft, Inc. 2004). Among-plot patterns in plant community composition were examined with nonmetric multidimensional scaling (NMS; McCune and Grace 2002). NMS analyses were performed using PC-ORD v. 4.34 for Windows (McCune and Mefford 1999). In Statistica, correlation and multiple-regression analyses were used to relate plot scores derived from the NMS ordination with raw environmental variables and with synthetic environmental variables extracted with PCA. In addition to these ordinations, we present figures 
illustrating among-plot variations in milk-vetch frequency and brome cover in relation to soiltexture classes.

\section{Results and Discussion}

\section{Population Surveys and Seedling Mortality}

Table 1 summarizes results of spring 2006 population surveys conducted by USGS and other investigators. A notable result of these surveys was the USGS discovery that the milk-vetch population at the Shivwits Paiute Reservation occurs on two distinct geologic substrates - the Triassic Petrified Forest Member of the Chinle Formation (TRcp) and the Jurassic Dinosaur Canyon Member of the Moenave Formation (Jmd) (see Biek et al. 2000). Although over 99 percent of all known individual plant occurrences are associated with the Petrified Forest Member (Table 1), the occurrence of milk-vetch plants on the fine-grained Dinosaur Canyon Member and the relatively wide range of soil characteristics at Petrified Forest Member sites supporting milkvetch populations have important implications for our understanding of the species' potential habitat. On the Petrified Forest Member, Shivwits milk-vetch occurrences span the full thickness of this highly variable sedimentary unit - from the very top of the unit where it contacts the Dinosaur Canyon Member (Shivwits and Pahcoon sites), to the middle of the unit (Zion Hilltop and Trailside sites), to the very bottom of the unit just above its contact with the Shinarump Member of the Chinle Formation (Zion Petrified Forest site).

The other notable result of the spring 2006 surveys was the enumeration of larger numbers of milk-vetch plants than had previously been documented at the Zion Hilltop and Trailside sites (Table 1). Together, these two sites accounted for 85 percent of established plants and over 75 percent of total plants (including seedlings) enumerated in spring 2006. Within an area less than 0.3 ha, the Hilltop site alone accounted for 63.5 percent of established plants and 60.5 percent of all known milk-vetch plants.

Over the 1-mo period from 20 April to 23 May, seedling mortality in 12 plots at the Zion Hilltop site ranged from 30.0 to 92.3 percent, with an average of 59.8 percent $(\mathrm{CV}=26.1)$. Correlation analyses found no significant linear relations between percent seedling mortality and measures of litter, rock, and plant cover.

Table 1. Results of Shivwits milk-vetch population surveys conducted during April-May 2006 (TRcp $=$ Petrified Forest Member of the Chinle Formation; Jmd = Dinosaur Canyon Member of the Moenave Formation). 


\begin{tabular}{|c|c|c|c|c|c|c|c|c|c|}
\hline \multirow[b]{2}{*}{ Population } & \multirow[b]{2}{*}{ Site $^{*}$ (ownership) } & \multicolumn{2}{|c|}{ Established plants } & \multicolumn{2}{|c|}{ Seedlings } & \multirow[b]{2}{*}{$\begin{array}{l}\text { GRAND } \\
\text { TOTAL }\end{array}$} & \multirow{2}{*}{$\begin{array}{l}\text { Pct of } \\
\text { Grand } \\
\text { Total }\end{array}$} & \multirow[b]{2}{*}{$\begin{array}{l}\text { Geologic } \\
\text { substrate }\end{array}$} & \multirow[b]{2}{*}{ Comments } \\
\hline & & Individuals & $\begin{array}{l}\text { Pct of } \\
\text { total }\end{array}$ & Individuals & $\begin{array}{c}\text { Pet of } \\
\text { total }\end{array}$ & & & & \\
\hline Coral Canyon & $\begin{array}{l}\text { Coral Canyon* } \\
\text { (private) }\end{array}$ & 72 & 37.5 & 120 & 62.5 & 192 & 4.6 & TRcp & \\
\hline $\begin{array}{l}\text { Pahcoon Spring } \\
\text { Wash }\end{array}$ & $\begin{array}{l}\text { Pahcoon Spring } \\
\text { Wash (BLM) }\end{array}$ & - & - & - & - & $400^{* *}$ & 9.5 & TRcp & \\
\hline \multirow{2}{*}{ Shivwits } & Chinle* (Tribal) $^{*}$ & 11 & 100.0 & 0 & 0.0 & 11 & 0.3 & TRcp & \\
\hline & Moenave* (Tribal) & 12 & 46.2 & 14 & 53.8 & 26 & 0.6 & Jmd & \\
\hline \multirow{2}{*}{$\begin{array}{l}\text { Harrisburg } \\
\text { Junction }\end{array}$} & $\begin{array}{l}\text { Harrisburg Bench* } \\
(\mathrm{BLM})\end{array}$ & 174 & 59.6 & 118 & 40.4 & 292 & 6.9 & TRcp & \\
\hline & Cottonwood (BLM) & - & - & - & - & $50^{* * *}$ & 1.2 & TRcp & \\
\hline Silver Reef & Silver Reef (BLM) & - & - & - & - & $12^{* * *}$ & 0.3 & TRcp & \\
\hline \multirow[t]{4}{*}{ Zion } & Hilltop* (NPS) & 1307 & 51.4 & 1238 & 48.6 & 2545 & 60.5 & TRcp & $\begin{array}{l}\text { Experimental site for } \\
\text { investigations of herbivory and } \\
\text { exotic-plant effects. Location of } \\
\text { automated precipitation gage and } \\
\text { soil-moisture sensors. }\end{array}$ \\
\hline & Trailside* (NPS) & 450 & 69.8 & 195 & 30.2 & 645 & 15.3 & TRcp & \\
\hline & $\begin{array}{l}\text { Petrified Forest* } \\
\text { (NPS) }\end{array}$ & 32 & 100.0 & 0 & 0.0 & 32 & 0.8 & TRcp & $\begin{array}{l}\text { Nearly all reproductive shoots } \\
\text { consumed by herbivores }\end{array}$ \\
\hline & GRAND TOTAL & 2058 & - & 1685 & - & 4205 & & & \\
\hline
\end{tabular}

* Sites surveyed by USGS in April-May 2006

** Estimate provided by Dr. Renee Van Buren, Utah Valley State College

${ }^{* * *}$ Data from USFWS (2006)

\section{Reproductive Output and Effects of Native Vertebrate Herbivory}

Herbivory by native vertebrates had statistically significant effects on numbers of reproductive shoots and fruits produced by milk-vetch plants, but did not significantly affect canopy volume (Table 2). Inside cages, 22 and 15 of 62 plants had reproductive shoots and produced fruit, respectively. Outside cages, 18 and 2 of 62 plants had reproductive shoots and produced fruit, respectively. (See histograms in Appendix B.)

These data suggest a 90 percent reduction in fruit production due to herbivory, and they illustrate the capacity of native herbivores to severely limit reproductive output in small, geographically constrained milk-vetch populations - particularly in dry years when reproductive output is already limited by resource availability. All 32 plants in the Petrified Forest subpopulation at Zion showed signs of extensive herbivory by vertebrates, with nearly all reproductive shoots consumed. Based on field observations (infrequent ungulate tracks, abundance of lagomorph dung, sightings of lagomorphs, and beveled cuts on stems), the most likely herbivores responsible for milk-vetch herbivory in this study were lagomorphs. The high degree of herbivory at this location may explain the observation that this was the only subpopulation where no seedlings were found during sampling in spring 2006. These results suggest that management actions which affect the distribution and abundance of small herbivores (and/or their predators) in proximity to milk-vetch populations may indirectly affect dynamics of those populations through effects on reproduction and replenishment of the seed bank.

Compared with results of this study, Tepedino (2005) found much higher levels of fruit production in his recent work on Shivwits milk-vetch. In a set of 30 plants at Harrisburg Junction in spring 2005, he found averages of 111.9 flowers per plant and 80 percent fruit set, resulting in an estimate of 89.5 fruits per plant. Aside from the effects of herbivory, low levels of fruit production at the Zion Hilltop site in 2006 likely were attributable to the relatively dry winter. During the October 2005 - March 2006 period, Zion NP received $198 \mathrm{~mm}$ of precipitation, which is approximately 85 percent of the long-term average of $231 \mathrm{~mm}$ (only 50 percent of the long-term average was 
received during the October-February period). In contrast, the October 2004 - March 2005 period preceding Tepedino's work was the wettest in the 78-year record, with $630 \mathrm{~mm}$ of precipitation recorded for Zion NP.

Table 2. Mean estimates of canopy volume and numbers of reproductive shoots and fruits produced by caged and uncaged Shivwits milk-vetch plants at the Zion Hilltop site in spring 2006.

\begin{tabular}{|c|c|c|c|c|c|c|}
\hline \multirow[b]{2}{*}{ Variable } & \multicolumn{2}{|c|}{ Caged plants $(n=62)$} & \multicolumn{2}{|c|}{ Uncaged plants $(n=62)$} & \multicolumn{2}{|c|}{ Wilcoxon Matched Pairs Test } \\
\hline & Mean & $\mathrm{CV}^{*}$ & Mean & CV & $\mathrm{Z}$ & $p$ \\
\hline $\begin{array}{l}\text { No. reproductive } \\
\text { shoots per plant }\end{array}$ & 1.27 & 191.7 & 0.50 & 197.6 & 2.46 & 0.014 \\
\hline No. fruits per plant & 3.37 & 249.7 & 0.34 & 651.9 & 2.93 & 0.003 \\
\hline $\begin{array}{l}\text { Estimated canopy } \\
\text { volume }\left(\mathrm{cm}^{3}\right)^{* \star}\end{array}$ & $4,106.0$ & 97.3 & $3,177.7$ & 85.0 & 1.59 & 0.112 \\
\hline
\end{tabular}

${ }^{*}$ Coefficient of variation $(\mathrm{CV})=100 \times$ (standard deviation / mean)

* Canopy volume was estimated by multiplying plant height (in $\mathrm{cm}$ ) by measures of maximum and minimum canopy width (in $\mathrm{cm}$ ).

Because of the low level of fruit production in spring 2006, we collected only 49 filled seeds from a total of 15 plants at the Zion Hilltop site. During Jan-Apr 2007, these seeds will be used in pilot studies of germination and growth requirements to support work planned for spring-summer 2007 (Research Objective 3). Based on Tepedino's (2005) estimate of 7 seeds per fruit and our estimate of 632 fruits produced by the entire Hilltop subpopulation ( 209 fruits produced by 62 caged plants, and an estimate of 423 fruits produced by 1245 uncaged plants), this level of seed collection represents approximately 1.1 percent of the 2006 seed crop for the Hilltop subpopulation. Because our study design for Research Objective 2 called for 500 seeds, we will not be able to augment experimental plots with milk-vetch seeds to assess effects of invasive exotic plants on seedling establishment in spring 2007.

\section{Descriptive Soil-Vegetation Sampling}

\section{Range-Wide Patterns}

Twenty soil-vegetation plots were sampled during April-May 2006 (Table 3; Appendices A and C), with Shivwits milk-vetch occurring in 17 of these. The remaining three plots at the Coral Canyon, Pahcoon, and Harrisburg Bench sites were sampled to examine factors potentially responsible for abrupt boundaries between soil-vegetation patches with and without milk-vetch plants. Table 4 summarizes ranges, means, and variability of selected measures associated with the 17 plots supporting Shivwits milk-vetch plants. With respect to milk-vetch measures, the 
Table 3. Summary of selected environmental and vegetation data for 20 soil-vegetation plots sampled during April-May 2006. Data for rock fragments $(>2 \mathrm{~mm})$ are percentages of the entire 0-10 cm sample by mass; data for sand, silt, and clay are percentages of the fine-earth fraction $(<$ $2 \mathrm{~mm}$ ) by volume. See Appendix $\mathrm{C}$ for detailed plot-level vegetation and ground-cover data.

\begin{tabular}{|c|c|c|c|c|c|c|}
\hline $\begin{array}{l}\text { Plot name } \\
\text { Plot code } \\
\text { (no. } 1-\mathrm{m}^{2} \text { quadrats) }\end{array}$ & Elevation & $\begin{array}{l}\text { Slope } \\
\text { Aspect } \\
\text { Heat-load index }\end{array}$ & $\begin{array}{l}\text { Shivwits milk-vetch } \\
\text { measures } \\
\text { Mean cover }\left(\mathrm{CV}^{*}\right) \\
1-\mathrm{m}^{2} \text { frequency } \\
\text { Total density }\end{array}$ & $\begin{array}{l}\text { Total live cover (CV) } \\
\text { Relative cover, exotics (CV) } \\
\text { Total rock cover (CV) }\end{array}$ & $\begin{array}{l}\text { Geologic substrate } \\
\text { USDA texture class, } 0-10 \mathrm{~cm}\end{array}$ & $\begin{array}{l}\text { Soil properties, } \\
0-10 \mathrm{~cm} \text { depth } \\
\text { Rock fragments } \\
\text { Sand } \\
\text { Silt } \\
\text { Clay } \\
\end{array}$ \\
\hline \multicolumn{7}{|l|}{ Zion National Park } \\
\hline $\begin{array}{l}\text { Hilltop CORA } 1 \\
\text { ZH_C1 } \\
(12)\end{array}$ & $1280 \mathrm{~m}$ & $\begin{array}{r}8 \mathrm{deg} \\
220 \mathrm{deg} \\
0.924\end{array}$ & $\begin{array}{l}0.1 \text { pct }(346.4) \\
8.3 \text { pct } \\
0.1 \text { plants } \mathrm{m}^{-2}\end{array}$ & $\begin{array}{l}13.2 \operatorname{pct}(71.0) \\
25.0 \operatorname{pct}(57.3) \\
5.2 \operatorname{pct}(171.7)\end{array}$ & $\begin{array}{l}\text { Petrified Forest Member } \\
\text { Sandy clay loam }\end{array}$ & $\begin{array}{r}1.7 \text { pct } \\
46.1 \text { pct } \\
27.9 \text { pct } \\
26.0 \text { pct }\end{array}$ \\
\hline $\begin{array}{l}\text { Hilltop CORA } 2 \\
\text { ZH_C2 } \\
(12)\end{array}$ & 1279 m & $\begin{array}{r}9 \mathrm{deg} \\
212 \mathrm{deg} \\
0.937\end{array}$ & $\begin{array}{l}0.1 \mathrm{pct}(346.4) \\
8.3 \text { pct } \\
0.1 \text { plants } \mathrm{m}^{-2}\end{array}$ & $\begin{array}{r}25.0 \text { pct }(65.9) \\
33.6 \text { pct }(46.6) \\
2.0 \text { pct }(85.3)\end{array}$ & $\begin{array}{l}\text { Petrified Forest Member } \\
\text { Loam }\end{array}$ & $\begin{array}{r}7.1 \text { pct } \\
39.8 \text { pct } \\
42.8 \text { pct } \\
17.4 \text { pct }\end{array}$ \\
\hline $\begin{array}{l}\text { Hilltop ASAM Lo } \\
\text { ZH_Lo } \\
(12)\end{array}$ & 1283 m & $\begin{array}{r}13 \mathrm{deg} \\
312 \mathrm{deg} \\
0.870\end{array}$ & $\begin{array}{l}0.2 \mathrm{pct}(346.4) \\
8.3 \text { pct } \\
0.2 \text { plants } \mathrm{m}^{-2}\end{array}$ & $\begin{array}{l}15.8 \operatorname{pct}(64.8) \\
92.3 \operatorname{pct}(9.6) \\
2.1 \operatorname{pct}(47.8)\end{array}$ & $\begin{array}{l}\text { Petrified Forest Member } \\
\text { Clay }\end{array}$ & $\begin{array}{r}6.2 \text { pct } \\
7.1 \text { pct } \\
36.9 \text { pct } \\
56.0 \text { pct }\end{array}$ \\
\hline $\begin{array}{l}\text { Hilltop ASAM Hi } 1 \\
\text { ZH_H1 } \\
(12)\end{array}$ & 1283 m & $\begin{array}{r}13 \mathrm{deg} \\
312 \mathrm{deg} \\
0.870\end{array}$ & $\begin{array}{l}2.0 \text { pct }(64.0) \\
91.7 \text { pct } \\
2.8 \text { plants } \mathrm{m}^{-2}\end{array}$ & $\begin{array}{r}18.8 \text { pct }(20.6) \\
49.4 \operatorname{pct}(34.6) \\
3.7 \operatorname{pct}(63.0)\end{array}$ & $\begin{array}{l}\text { Petrified Forest Member } \\
\text { Silty clay loam }\end{array}$ & $\begin{array}{l}\text { 13.3 pct } \\
19.7 \text { pct } \\
42.4 \text { pct } \\
37.8 \text { pct }\end{array}$ \\
\hline $\begin{array}{l}\text { Hilltop ASAM Hi } 2 \\
\text { ZH_H2 } \\
(12)\end{array}$ & 1284 m & $\begin{array}{r}8 \mathrm{deg} \\
300 \mathrm{deg} \\
0.888\end{array}$ & $\begin{array}{l}1.7 \text { pct }(82.2) \\
83.3 \text { pct } \\
3.4 \text { plants } \mathrm{m}^{-2}\end{array}$ & $\begin{array}{r}19.8 \text { pct }(54.1) \\
65.0 \text { pct }(22.8) \\
3.0 \text { pct }(47.1)\end{array}$ & $\begin{array}{l}\text { Petrified Forest Member } \\
\text { Gravelly silty clay }\end{array}$ & $\begin{array}{l}17.6 \text { pct } \\
21.2 \text { pct } \\
37.0 \text { pct } \\
41.9 \text { pct }\end{array}$ \\
\hline $\begin{array}{l}\text { Hilltop ASAM Hi } 3 \\
\text { ZH_H3 } \\
(12)\end{array}$ & $1280 \mathrm{~m}$ & $\begin{array}{r}8 \mathrm{deg} \\
200 \mathrm{deg} \\
0.931\end{array}$ & $\begin{array}{l}1.3 \mathrm{pct}(77.2) \\
83.3 \text { pct } \\
3.3 \text { plants } \mathrm{m}^{-2}\end{array}$ & $\begin{array}{r}20.8 \text { pct }(36.3) \\
80.0 \text { pct }(15.6) \\
1.6 \text { pct }(73.5)\end{array}$ & $\begin{array}{l}\text { Petrified Forest Member } \\
\text { Silty clay }\end{array}$ & $\begin{array}{r}2.9 \text { pct } \\
11.7 \text { pct } \\
42.7 \text { pct } \\
45.6 \text { pct }\end{array}$ \\
\hline $\begin{array}{l}\text { Trail North } \\
\mathrm{ZT} N \mathrm{~N} \\
(17)\end{array}$ & 1255 m & $\begin{array}{r}10 \mathrm{deg} \\
264 \mathrm{deg} \\
0.943\end{array}$ & $\begin{array}{l}1.1 \text { pct }(83.0) \\
70.6 \text { pct } \\
2.1 \text { plants } \mathrm{m}^{-2}\end{array}$ & $\begin{array}{r}14.5 \mathrm{pct}(35.8) \\
40.3 \operatorname{pct}(40.5) \\
8.8 \operatorname{pct}(82.0)\end{array}$ & $\begin{array}{l}\text { Petrified Forest Member } \\
\text { Gravelly loam }\end{array}$ & $\begin{array}{l}22.4 \text { pct } \\
40.3 \text { pct } \\
37.9 \text { pct } \\
21.9 \text { pct }\end{array}$ \\
\hline
\end{tabular}

${ }^{*}$ Coefficient of variation $(\mathrm{CV})=100 \times$ (standard deviation / mean) 
Table 3, continued.

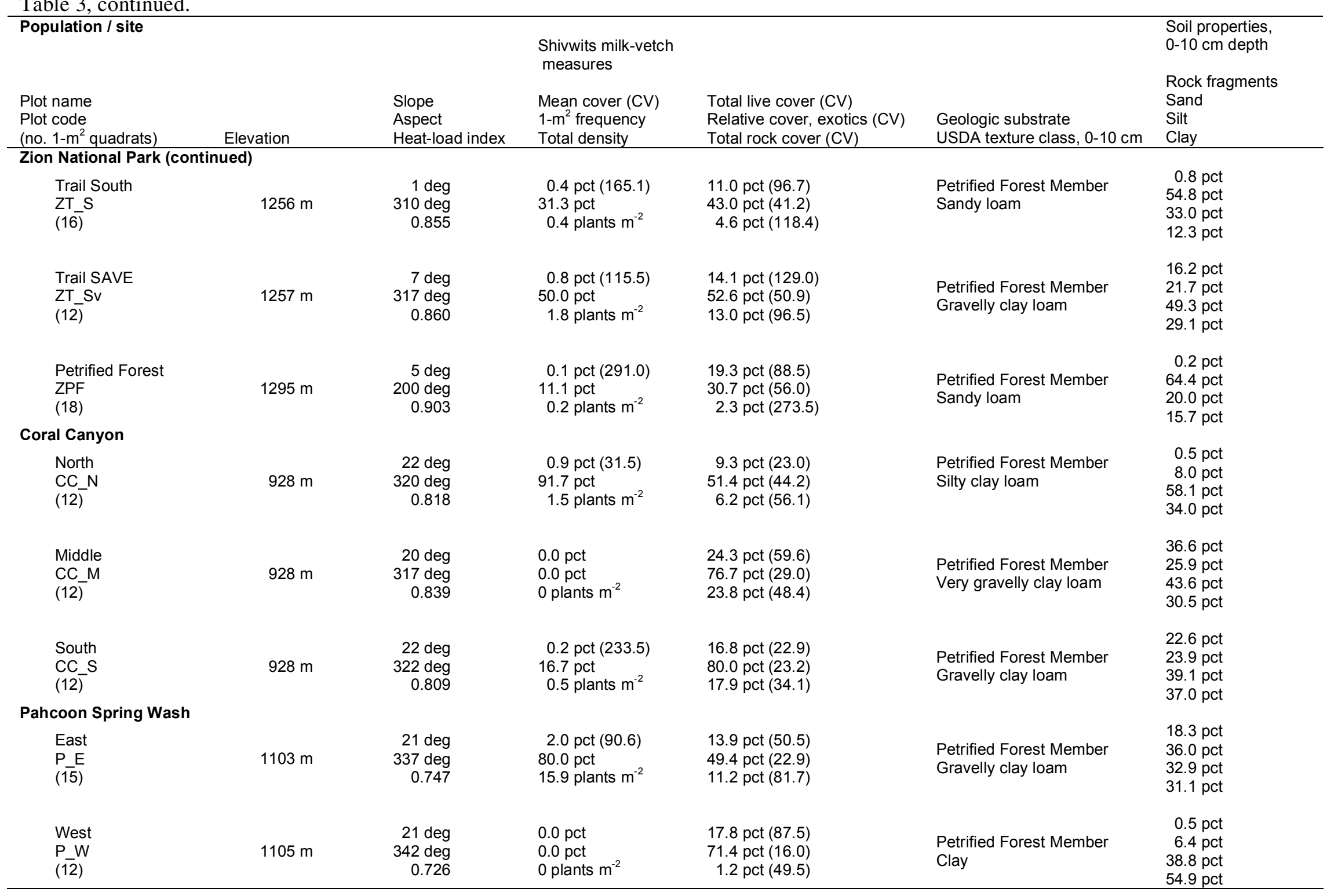


Table 3, continued.

\begin{tabular}{|c|c|c|c|c|c|c|}
\hline Population / site & & & $\begin{array}{l}\text { Shivwits milk-vetch } \\
\text { measures }\end{array}$ & & & $\begin{array}{l}\text { Soil properties, } \\
0-10 \mathrm{~cm} \text { depth }\end{array}$ \\
\hline $\begin{array}{l}\text { Plot name } \\
\text { Plot code } \\
\text { (no. } 1-\mathrm{m}^{2} \text { quadrats) }\end{array}$ & Elevation & $\begin{array}{l}\text { Slope } \\
\text { Aspect } \\
\text { Heat-load index }\end{array}$ & $\begin{array}{l}\text { Mean cover }(\mathrm{CV}) \\
1-\mathrm{m}^{2} \text { frequency } \\
\text { Total density }\end{array}$ & $\begin{array}{l}\text { Total live cover (CV) } \\
\text { Relative cover, exotics (CV) } \\
\text { Total rock cover (CV) }\end{array}$ & $\begin{array}{l}\text { Geologic substrate } \\
\text { USDA texture class, } 0-10 \mathrm{~cm}\end{array}$ & $\begin{array}{l}\text { Rock fragments } \\
\text { Sand } \\
\text { Silt } \\
\text { Clay }\end{array}$ \\
\hline \multicolumn{7}{|l|}{ Harrisburg Bench } \\
\hline $\begin{array}{l}\text { Chinle Lower } \\
\text { H_CL } \\
(20)\end{array}$ & $961 \mathrm{~m}$ & $\begin{array}{r}8 \mathrm{deg} \\
008 \mathrm{deg} \\
0.771\end{array}$ & $\begin{array}{l}0.8 \text { pct }(96.0) \\
65.0 \text { pct } \\
1.6 \text { plants } \mathrm{m}^{-2}\end{array}$ & $\begin{array}{l}15.6 \text { pct }(35.3) \\
74.4 \text { pct }(22.2) \\
5.9 \text { pct }(173.3)\end{array}$ & $\begin{array}{l}\text { Petrified Forest Member } \\
\text { Clay }\end{array}$ & $\begin{array}{r}4.9 \text { pct } \\
14.9 \text { pct } \\
27.3 \text { pct } \\
57.8 \text { pct }\end{array}$ \\
\hline $\begin{array}{l}\text { Chinle Upper } \\
\text { H_CU } \\
(16)\end{array}$ & $964 \mathrm{~m}$ & $\begin{array}{r}9 \text { deg } \\
000 \text { deg } \\
0.774\end{array}$ & $\begin{array}{l}0.0 \mathrm{pct} \\
0.0 \mathrm{pct} \\
0 \text { plants } \mathrm{m}^{-2}\end{array}$ & $\begin{array}{l}27.9 \operatorname{pct}(34.1) \\
97.3 \operatorname{pct}(2.5) \\
16.2 \operatorname{pct}(67.3)\end{array}$ & $\begin{array}{l}\text { Petrified Forest Member } \\
\text { Clay loam }\end{array}$ & $\begin{array}{r}8.2 \text { pct } \\
40.0 \text { pct } \\
27.1 \text { pct } \\
32.9 \text { pct }\end{array}$ \\
\hline $\begin{array}{l}\text { Gravel Surface } \\
\text { H_GS } \\
(16)\end{array}$ & $961 \mathrm{~m}$ & $\begin{array}{r}8 \mathrm{deg} \\
330 \mathrm{deg} \\
0.837\end{array}$ & $\begin{array}{l}0.1 \text { pct }(273.3) \\
12.5 \text { pct } \\
0.1 \text { plants } \mathrm{m}^{-2}\end{array}$ & $\begin{array}{l}22.3 \operatorname{pct}(36.4) \\
77.0 \operatorname{pct}(13.3) \\
19.7 \operatorname{pct}(82.4)\end{array}$ & $\begin{array}{l}\text { Petrified Forest Member } \\
\text { Clay }\end{array}$ & $\begin{array}{r}2.0 \text { pct } \\
29.9 \text { pct } \\
27.4 \text { pct } \\
42.7 \text { pct }\end{array}$ \\
\hline \multicolumn{7}{|c|}{ Shivwits Paiute Reservation } \\
\hline $\begin{array}{l}\text { Chinle } \\
\text { S_C } \\
(16)\end{array}$ & $1037 \mathrm{~m}$ & $\begin{array}{r}7 \mathrm{deg} \\
010 \mathrm{deg} \\
0.779\end{array}$ & $\begin{array}{l}0.1 \text { pct }(273.3) \\
12.5 \text { pct } \\
0.6 \text { plants } \mathrm{m}^{-2}\end{array}$ & $\begin{array}{l}\text { 11.4 pct }(59.1) \\
\text { 83.4 pct }(11.9) \\
\text { 14.1 pct }(49.1)\end{array}$ & $\begin{array}{l}\text { Petrified Forest Member } \\
\text { Silty clay loam }\end{array}$ & $\begin{array}{r}8.4 \text { pct } \\
18.7 \text { pct } \\
42.0 \text { pct } \\
39.2 \text { pct }\end{array}$ \\
\hline $\begin{array}{l}\text { Moenave } \\
\text { S_M } \\
(12)\end{array}$ & $1027 \mathrm{~m}$ & $\begin{array}{c}\text { Variable } \\
\text { Variable } \\
0.838\end{array}$ & $\begin{array}{l}0.3 \text { pct }(195.4) \\
25.0 \text { pct } \\
0.5 \text { plants } \mathrm{m}^{-2}\end{array}$ & $\begin{array}{r}9.2 \text { pct }(69.1) \\
69.0 \text { pct }(43.0) \\
1.0 \text { pct }(0.0)\end{array}$ & $\begin{array}{l}\text { Dinosaur Canyon Member } \\
\text { Clay }\end{array}$ & $\begin{array}{r}3.9 \text { pct } \\
5.0 \text { pct } \\
38.0 \text { pct } \\
57.0 \text { pct }\end{array}$ \\
\hline
\end{tabular}


Pahcoon East plot is particularly noteworthy relative to the others since average milk-vetch density $\left(15.9\right.$ plants $\left.\mathrm{m}^{-2}\right)$ there was more than 7.5 times the average measure $\left(2.1\right.$ plants $\left.\mathrm{m}^{-2}\right)$ for all milkvetch plots combined (Tables 3 and 4). This plot is coincident with Dr. Renee Van Buren's longterm demographic monitoring plot. Approximately 44 percent of the milk-vetch plants in this plot were seedlings (Table C6, Appendix C), a value that is generally similar to those found during surveys of other population locations in spring 2006 (Table 1).

Table 4. Ranges, means, and coefficients of variation (CV) of selected environmental, milk-vetch, and vegetation cover variables for the 17 soilvegetation plots in which Shivwits milk-vetch was found to occur, April-May 2006.

\begin{tabular}{|c|c|c|c|c|}
\hline Variables & Minimum & Maximum & Mean & $\mathrm{CV}^{*}$ \\
\hline \multicolumn{5}{|l|}{ Environmental } \\
\hline Elevation (m) & 928 & 1295 & 1158.6 & 12.9 \\
\hline Heat-load index & 0.75 & 0.94 & 0.86 & 7.0 \\
\hline Sand, $0-10 \mathrm{~cm}(\mathrm{pct})$ & 5.0 & 64.4 & 27.2 & 63.5 \\
\hline Clay, $0-10 \mathrm{~cm}$ (pct) & 12.3 & 57.8 & 35.4 & 39.9 \\
\hline Rock cover (pct) & 1.0 & 19.7 & 7.2 & 82.3 \\
\hline \multicolumn{5}{|l|}{ Milk-vetch } \\
\hline $1-m^{2}$ frequency (pct) & 8.3 & 91.7 & 44.1 & 76.7 \\
\hline Density (plants $\mathrm{m}^{-1}$ ) & 0.1 & 15.9 & 2.1 & 181.3 \\
\hline \multicolumn{5}{|l|}{ Vegetation cover } \\
\hline Total live cover (pct) & 9.2 & 25.0 & 15.9 & 28.6 \\
\hline Relative exotic cover (pct) & 25.0 & 92.3 & 58.6 & 35.1 \\
\hline Red brome cover (pct) & 1.8 & 15.8 & 6.9 & 61.0 \\
\hline Cheatgrass cover (pct) & 0.0 & 8.0 & 1.6 & 151.7 \\
\hline
\end{tabular}

Across the 17 milk-vetch plots, average relative cover of exotic plants (i.e., the exotic proportion of total live cover) was 58.6 percent (Table 4), a substantially larger value than the 36.6 percent average that Van Buren and Harper (2003) found in their studies. Red brome and cheatgrass ( $B$. tectorum) were the two most abundant exotics, as well as the two most abundant plants overall, with average cover values of 6.9 and 1.6 percent, respectively. Though it was primarily restricted to Zion plots, galleta (Hilaria jamesii) was the most abundant native plant overall, with average cover of 1.0 percent among the 17 milk-vetch plots and 1.7 percent among the 10 Zion plots. At the range-wide scale, milk-vetch frequency in $1-\mathrm{m}^{2}$ quadrats was not correlated with total live cover $(\mathrm{r}=-0.29, \mathrm{p}=0.21)$ or relative cover of invasive exotic plants $(\mathrm{r}=-0.21, \mathrm{p}=0.37)$.

We found a large range in soil texture across the 17 plots supporting Shivwits milk-vetch plants (Tables 3 and 4). Although over 99 percent of Shivwits milk-vetch individuals were found to occur on gently sloping Petrified Forest Member outcrops, the rocks are heterogeneous consisting of smectitic shale, siltstone, sandstone, and conglomerate with pebble- to cobble-sized clasts (Willis et al. 2002). As noted earlier, milk-vetch occurrences span much of this heterogeneity across the full thickness of the geologic unit. In addition, milk-vetch settings receive 
varying amounts of material inputs from surrounding geologic deposits, including Quaternary landslide and alluvial deposits bearing materials derived from sandstones, conglomerates, and intrusive igneous rocks (Willis et al. 2002, Biek 2003). As a consequence, texture classes of milkvetch plots were found to vary from sandy loam (Zion Trail South and Petrified Forest plots) to clay (Zion Hilltop Asam Lo, Shivwits Moenave, and Harrisburg Chinle Lower and Gravel Surface plots; Table 3; Appendix D).

Principal components analysis of five environmental variables (elevation, topographic heat-load index, and three soil-texture fractions) extracted two principal components which together explained 78 percent of the among-plot variability in the original five variables (Table 5). Elevation and topographic heat load were highly correlated with Axis 1, whereas sand and silt (the latter negatively) were highly correlated with Axis 2.

Table 5. Loadings (Pearson correlation coefficients) of five environmental variables on PCA Axes 1 and 2. The PCA solution was rotated using the varimax normalization procedure in Statistica.

\begin{tabular}{lcc}
\hline Variable & Axis 1 & Axis 2 \\
\hline Elevation & 0.843 & 0.068 \\
Heat-load index & 0.906 & 0.030 \\
Pct sand, $0-10 \mathrm{~cm}$ & 0.377 & 0.912 \\
Pct silt, $0-10 \mathrm{~cm}$ & 0.195 & -0.812 \\
Pct clay, $0-10 \mathrm{~cm}$ & -0.584 & -0.597 \\
Proportion of total variation & 0.411 & 0.371 \\
\hline
\end{tabular}

Figure 1 illustrates the location of the 20 soil-vegetation plots in relation to the two environmental axes extracted with PCA. Plot elevations and heat-load indices were significantly correlated $(\mathrm{r}=$ $0.70, \mathrm{p}=0.001$ ), indicating that milk-vetch populations at higher elevation plots in Zion NP tended to occur in warmer topographic positions (higher topographic heat-load indices) relative to populations in lower elevation plots outside the Park (Figure 1; Table 3). This pattern might reflect some degree of habitat selectivity by milk-vetch populations, or it could be an artifact attributable to environmental characteristics of available habitat patches. At the range-wide scale, among-plot variability in milk-vetch frequency was not significantly correlated with variations in soil texture, although some trends in milk-vetch - soil texture relations were evident at individual study sites (see below). (See Appendix D for additional figures illustrating variations in milk-vetch frequency and brome cover in relation to soil-texture classes.)

As with milk-vetch frequency, total brome cover was not significantly correlated with variations in soil texture at the range-wide scale. However, patterns evident in Figure 1 suggest a possible elevation-by-texture interaction with respect to brome cover. In the 10 relatively high-elevation plots at Zion NP, total brome cover was positively correlated with $0-10 \mathrm{~cm}$ clay content $(\mathrm{r}=0.77, \mathrm{p}$ $=0.009)$ and negatively correlated with $0-10 \mathrm{~cm}$ sand content $(\mathrm{r}=-0.72, \mathrm{p}=0.018)$. In the 10 lower elevation plots outside of Zion NP, there was a tendency for total brome cover to be positively correlated with $0-10 \mathrm{~cm}$ sand content $(\mathrm{r}=0.61, \mathrm{p}=0.059)$. Site-specific brome-texture patterns are discussed in greater detail below. 


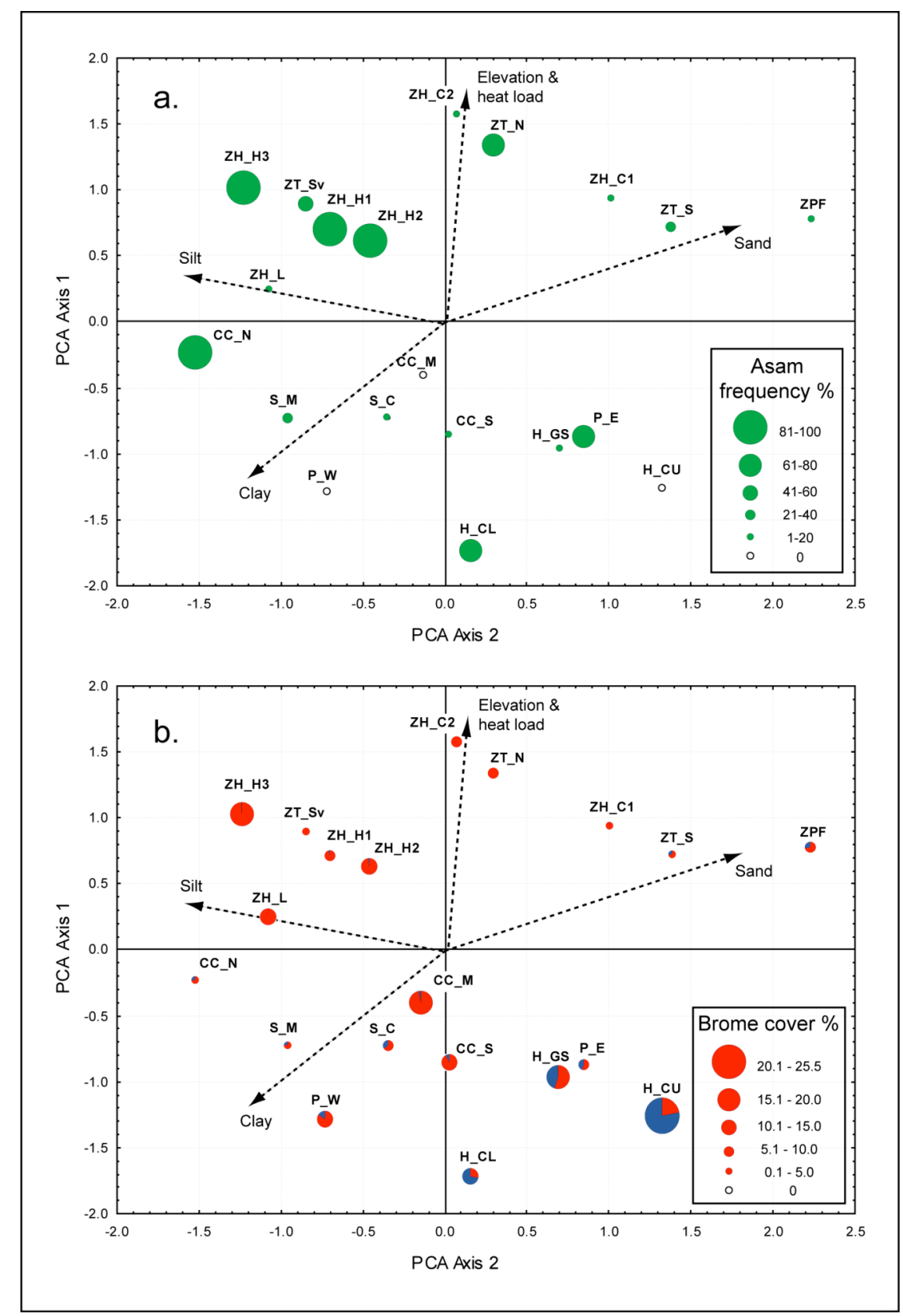

Figure 1. Ordination of 20 soil-vegetation plots in relation to PCA axes 1 and 2. In (a), point size is scaled by milk-vetch (Asam) frequency in $1-\mathrm{m}^{2}$ quadrats. In (b), point size is scaled by total cover of exotic annual brome grasses, with relative proportions of red brome and cheatgrass indicated by red and blue segments of the symbol, respectively. Dashed vectors indicate the relative loadings of elevation and heat load, sand, silt, and clay on axes 1 and 2. (Coordinates for the head of each environmental vector are twice the correlation coefficients associated with the two PCA axes.) See Table 3 for key to plot codes.

Our investigation of range-wide environmental relations is hampered by the small number of milkvetch occurrences (thereby limiting our sample size). We also have a poor quantitative understanding of how factors such as herbivory by native herbivores, competition from other plants, livestock grazing and trampling, off-road vehicle travel, and urbanization may have affected 
relative levels of milk-vetch and exotic plant abundance, thereby complicating our search for plantenvironment relations. Additional insights into plant-environment relations may emerge once the remainder of the soil data are received and analyzed.

Figure 2 illustrates the location of the 20 soil-vegetation plots in relation to two gradients in plant community composition extracted with NMS analyses. Axis 2 and axis 1 accounted for 43.3 and 29.9 percent of the among-plot variability in plant community composition, respectively. Because red brome and cheatgrass were the two most abundant plants overall, most of the among-plot variability in community composition was attributable to variations in the relative abundance of these two exotic grasses. Plot scores for NMS axis 2 were significantly correlated with cheatgrass cover $(\mathrm{r}=0.69, \mathrm{p}=0.001)$, total brome cover $(\mathrm{r}=0.44, \mathrm{p}=0.050)$ and relative cover of exotic plants $(\mathrm{r}=0.57, \mathrm{p}=0.008)$. Plot scores for NMS axis 2 were significantly correlated with red brome cover $(\mathrm{r}=-0.88, \mathrm{p}<0.001)$, total brome cover $(\mathrm{r}=-0.63, \mathrm{p}=0.003)$, and relative exotic cover $(r=-0.47, p=0.035)$. Milk-vetch frequency was not significantly correlated with plot scores for either NMS axis. (See Appendix C for detailed plot-level data on plant community composition.)

Regression analyses indicated that the gradients in community composition reflected by NMS axis 2 (cheatgrass abundance) and NMS axis 1 (red brome abundance) were significantly related to measured environmental variables. PCA axis 1 (positively related to elevation and heat load) was the best single predictor for NMS axis 2 (beta $=-0.799, \mathrm{R}^{2}=0.64, \mathrm{p}<0.00002$ ), and PCA axis 2 (positively related to $0-10 \mathrm{~cm}$ sand content) was the best (albeit weak) predictor for NMS axis 1 (beta $=0.469, \mathrm{R}^{2}=0.22, \mathrm{p}=0.037$ ).

\section{Site-Level Patterns}

Although range-wide relations between milk-vetch frequency and measured environmental variables were weak, spatial variations in milk-vetch frequency at study sites associated with several population locations appeared related to variations in soil texture and/or total rock cover. The Zion Hilltop site where more than 60 percent of all known milk-vetch plants occur is perched on an isolated mound which is an erosional remnant of a once-larger landslide deposit (Willis et al. 2002). The center of the mound where the milk-vetch plants occur is an unmapped Petrified Forest Member exposure analogous to a "donut hole" surrounded by sandstone-derived landslide debris ranging in size from large boulders to fine gravels. At this site, we sampled six soil-vegetation plots to examine relations between soil variables and site-level variations in milk-vetch frequency.

We found that milk-vetch frequency in Zion Hilltop plots varied in a curvilinear fashion in relation to trends in 0-10 cm sand and clay content (Table 3, Figure 3a). Milk-vetch frequencies were low at the sandy end of the texture gradient in plots CORA1 and CORA2, both of which were located at the interface between Petrified Forest Member exposures and surrounding landslide deposits and were co-dominated by blackbrush (Coleogyne ramosissima) and the exotic red brome (Table 3, Figure 3a). Milk-vetch frequency also was low at the clayey end of the texture gradient (plot Asam Lo), and was highest in three plots (Asam Hi1, Hi2, and Hi3) that were characterized with silty clay / silty clay loam textures (Table 3, Figure 3a). Relative to the plots with silty clay and silty clay loam textures, the clay plot with low milk-vetch frequency was in a geomorphic setting that may have received less material inputs from surrounding landslide deposits. In contrast with milkvetch patterns, density of the escaped exotic cultivar Moluccella laevis (Bells of Ireland, Lamiaceae) was highest in the clayey plot (21.6 plants $\mathrm{m}^{-2}$ ) relative to the silty clay / silty clay loam plots (3plot average of 0.8 plants $\mathrm{m}^{-2}$ ). Moluccella did not occur in the relatively sandy plots (see plot-level data in Appendix C). Total brome cover tended to vary inversely with $0-10 \mathrm{~cm}$ sand content $(\mathrm{n}=$ 
$6 ; \mathrm{r}=-0.80, \mathrm{p}=0.052 ;$ Figure $3 \mathrm{c}$ ). In addition to direct effects of soil properties, low abundances for milk-vetch, brome, and Moluccella in the sandiest plots may have been affected by the competitive presence of blackbrush.
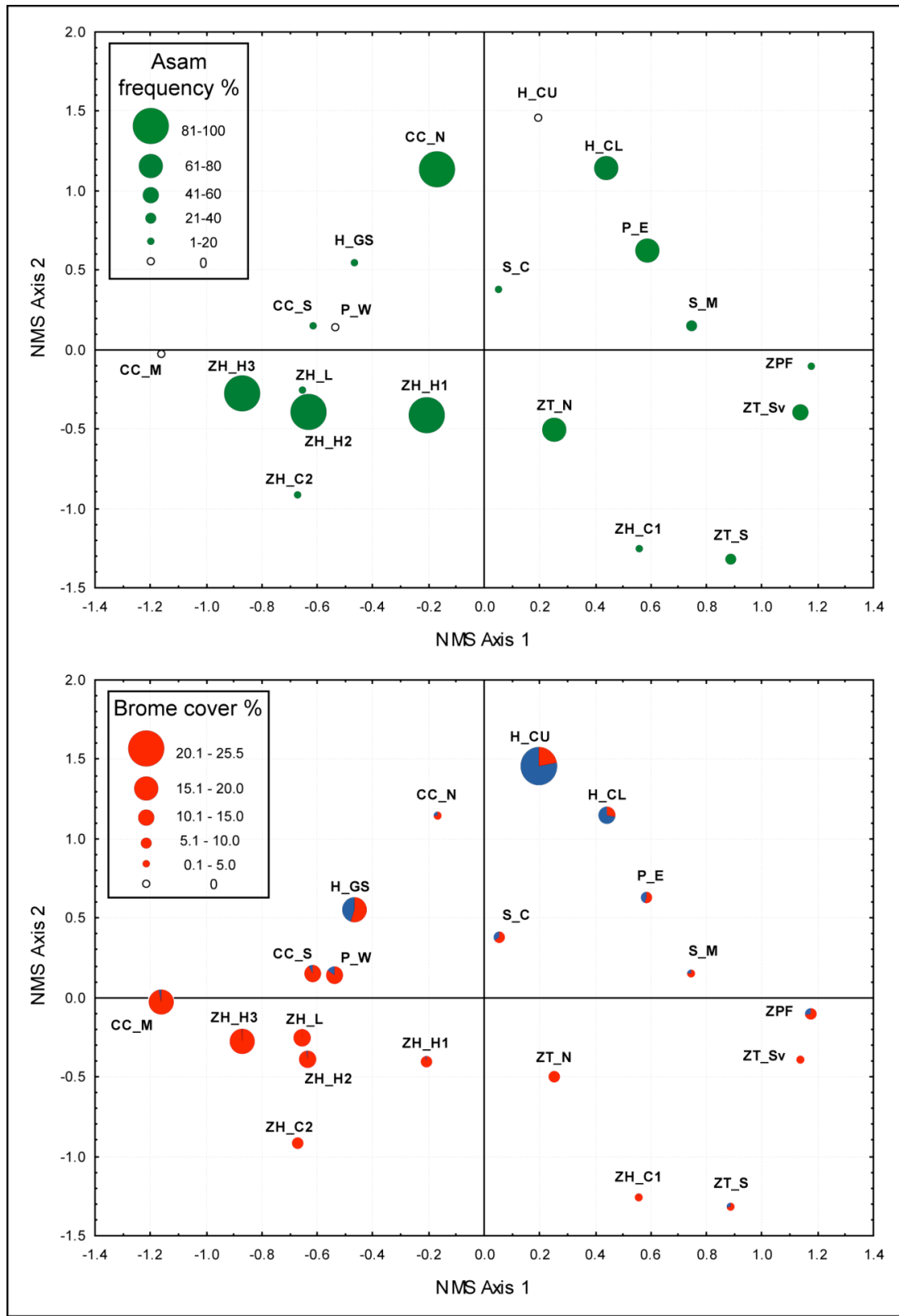

Figure 2. Ordination of 20 soil-vegetation plots in relation to NMS axes 1 and 2. In (a), point size is scaled by milk-vetch (Asam) frequency in $1-\mathrm{m}^{2}$ quadrats. In (b), point size is scaled by total cover of exotic annual brome grasses, with relative proportions of red brome and cheatgrass indicated by red and blue segments of the symbol, respectively. See Table 3 for key to plot codes. 


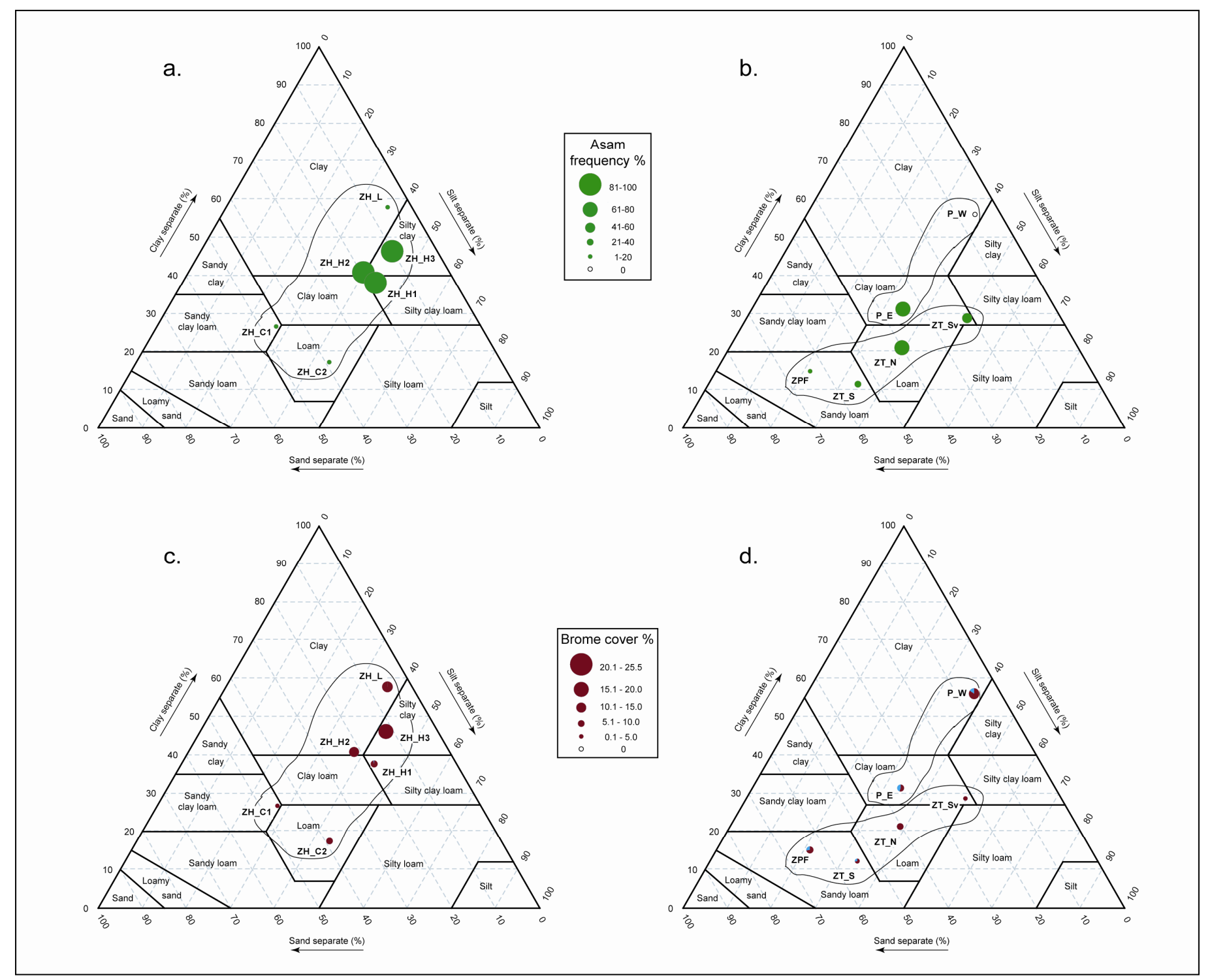

Figure 3. Graphs showing variations in milk-vetch (Asam) frequency and total brome cover in relation to 0-10 $\mathrm{cm}$ soil-texture classes at the Zion Hilltop site (a, c), the Zion Trailside site (b, d) and the Pahcoon Springs Wash site (d). In (c) and (d), relative proportions of red brome and cheatgrass are indicated by red and blue segments of symbols, respectively. See Table 3 for key to plot codes. 
Similar to the Hilltop site, plots at the Zion Trailside and Petrified Forest sites occurred on unmapped Petrified Forest Member patches in the midst of sandstone-dominated landslide complexes (Willis et al. 2002). Among these plots, milk-vetch frequencies were lowest at plots with sandy loam soils and highest at plots with loam and clay loam soils (Table 3; Figure 3b). Moluccella density was highest in the Zion Trail South plot (sandy loam soil; 4.5 plants $\mathrm{m}^{-2}$ ), although its abundance in this plot may have been reduced by past removals conducted by NPS staff and volunteers. Moluccella occurred in the Zion Trail SAVE plot (clay loam soil; 0.5 plants $\mathrm{m}-2$ ), but not in the Petrified Forest and Trail North plots. No brome-soil relations were evident among the three Trailside and Petrified Forest plots (Figure 3d).

At the Pahcoon Springs Wash site, we sampled two soil-vegetation plots to examine whether soil properties could explain an abrupt change in milk-vetch density from 15.9 plants $\mathrm{m}^{-2}$ in the Pahcoon East plot to a near-complete absence of milk-vetch plants in the Pahcoon West plot just a few meters away. (A few milk-vetch plants did occur within the plot area, but they were not present in the randomly located quadrats.) These plots were adjacent to one another on a northwest-facing hillslope, just west of the northwest-southeast trending contact of the Petrified Forest Member and Dinosaur Canyon Member (Hintze and Hammond 1994). Differences in soil coloration, texture, and abundance and lithology of rock fragments suggest that the two adjacent plots occurred on different facies of the Petrified Forest Member exposure. The high-density Pahcoon East plot was characterized by a gravelly clay loam soil (Figure 3b), with abundant limestone gravels weathering out of the Petrified Forest Member substrate. The adjacent Pahcoon West plot was characterized by a clay soil with much less sand (6.4 percent vs. 36.0 percent), much more clay (54.9 percent vs. 31.1 percent), and higher brome cover (13.9 percent vs. 6.8 percent) relative to the Pahcoon East plot (Figure 3d, Table 3, Appendix C).

Plots at the Coral Canyon site were on a northwest-facing Petrified Forest Member hillslope immediately below a bench formed by Quaternary fan gravels derived from the distant Pine Valley Mountains (Biek 2003). At this site, we sampled three soil-vegetation plots to describe distinct patterns in the relative abundance of milk-vetch and invasive exotic brome grasses (Figure 4). The Middle and South plots were armored with colluvial deposits consisting of sandstone and igneous cobbles and gravels from the fan surface above. The North plot occurred on a relatively unarmored slope that appeared to be protected from colluvial deposits by a boulder which occurred at the shoulder of the slope (Figure 4). Among the three plots at this site, we found that milk-vetch frequency decreased (Figure 5a) and total brome cover increased (Figure 5b) with increasing rock cover and $0-10 \mathrm{~cm}$ sand content attributable to colluvial deposits.

We found similar patterns with respect to rock cover, $0-10 \mathrm{~cm}$ sand content, milk-vetch frequency, and total brome cover at the Harrisburg site. At this site, all plots were located on Petrified Forest Member exposures, but plots varied in degree of rock armoring and 0-10 $\mathrm{cm}$ sand content due to differences in geomorphic setting. We located the Gravel Surface plot at the foot of a slope that was well-armored by rock cover derived from an upslope Quaternary talus deposit associated with the Shinarump (conglomerate) Member of the Chinle Formation (Trcs). The Chinle Lower plot was located at a similar footslope position on an adjacent surface which did not receive material inputs from the talus deposit. Upslope above the Chinle Lower plot, the gravel-armored Chinle Upper plot was in a setting that received material inputs from rocky landslide and alluvial-fan deposits located above. As at the Coral Canyon site, we found that milk-vetch frequency decreased (Figure 5a) and total brome cover increased (Figure 5b) with increasing rock cover and 0-10 cm sand content attributable to these among-plot differences in geomorphic setting and geologic inputs. 


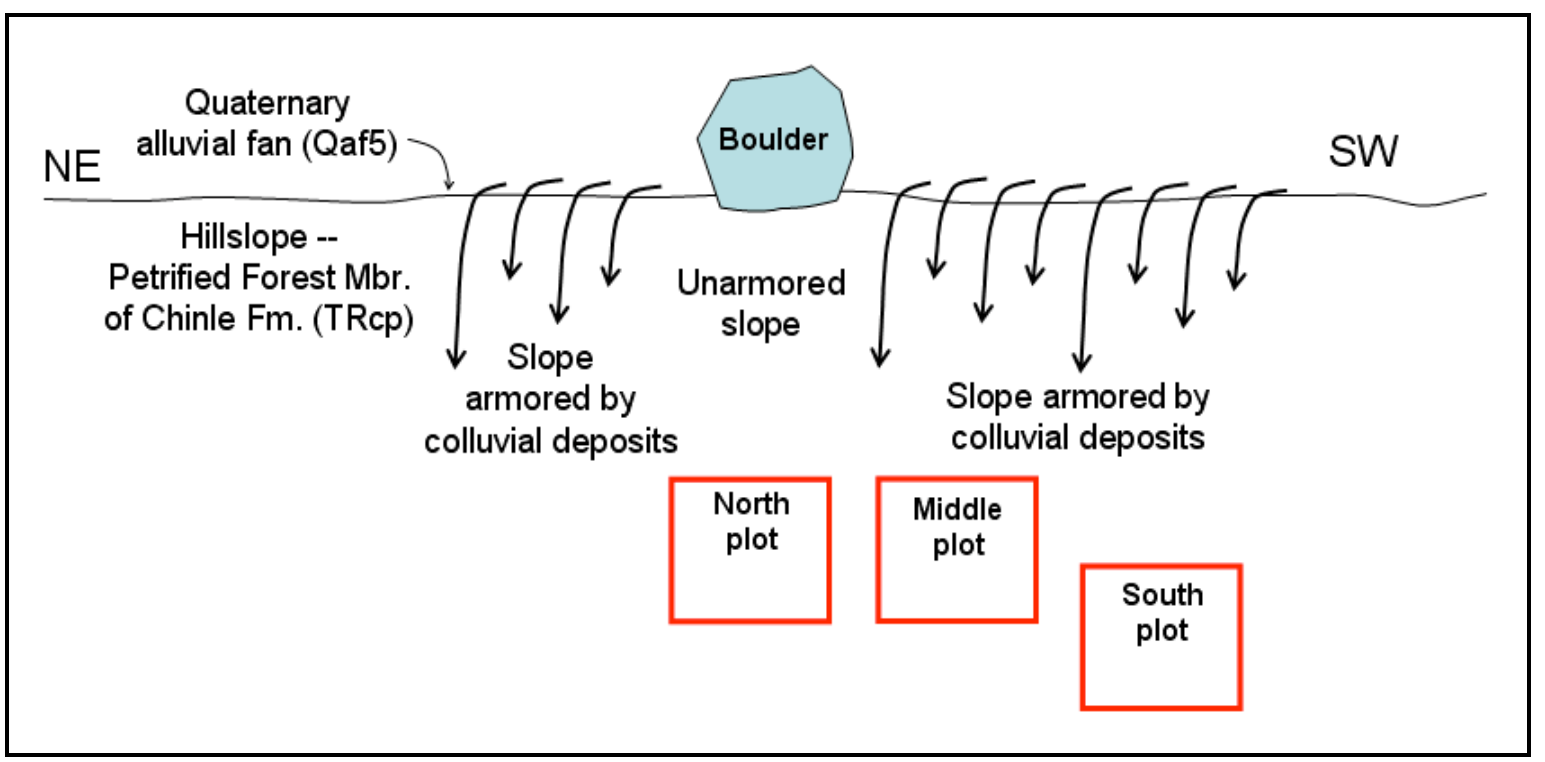

Figure 4. Cross-sectional diagram illustrating spatial configuration of soil-vegetation plots at the Coral Canyon site in relation to colluvium from the Quaternary alluvial fan (Qaf5 surface mapped by Biek 2003) which caps the Petrified Forest Member (TRcp) hillslope. Scale is approximately $50 \mathrm{~m}$ from left to right of figure.

Rock cover may influence milk-vetch and brome abundance at the Coral Canyon and Harrisburg sites through effects on seed retention and seedling establishment (i.e., availability of "safe sites" sensu Harper 1977). Seed catchment may be enhanced directly due to effects of rock cover on soil-surface roughness (e.g., Harper et al. 1965) and indirectly due to retarding effects of surface roughness on overland water flow and downslope seed movement. Increasing sand content in soils of these two low-elevation, fine-textured sites may enhance plant performance by reducing evaporative water losses (i.e., the "inverse texture effect" of Noy-Meir 1973). If one or both of these effects are more beneficial for brome grasses than for the milk-vetch, and if the milk-vetch responds adversely to brome competition, then this would explain opposite trends in milk-vetch and brome performance in relation to these physical soil properties.

At the Shivwits site, the milk-vetch population was too small and sparsely distributed to indicate spatial patterns suitable for investigation with comparative soil-vegetation plots. Instead, we sampled to compare soil properties of the two geologic substrates (Petrified Forest Member and Dinosaur Canyon Member) where milk-vetch plants occurred. The $0-10 \mathrm{~cm}$ soil in Chinle plot (Petrified Forest Member) was a silty clay loam with similar texture to the three high-frequency plots at the Zion Hilltop site (Table 3). The $0-10 \mathrm{~cm}$ soil in Moenave plot (Dinosaur Canyon Member) was clay with very similar texture to the Pahcoon West plot where no milk-vetch plants occurred in sampled quadrats. 


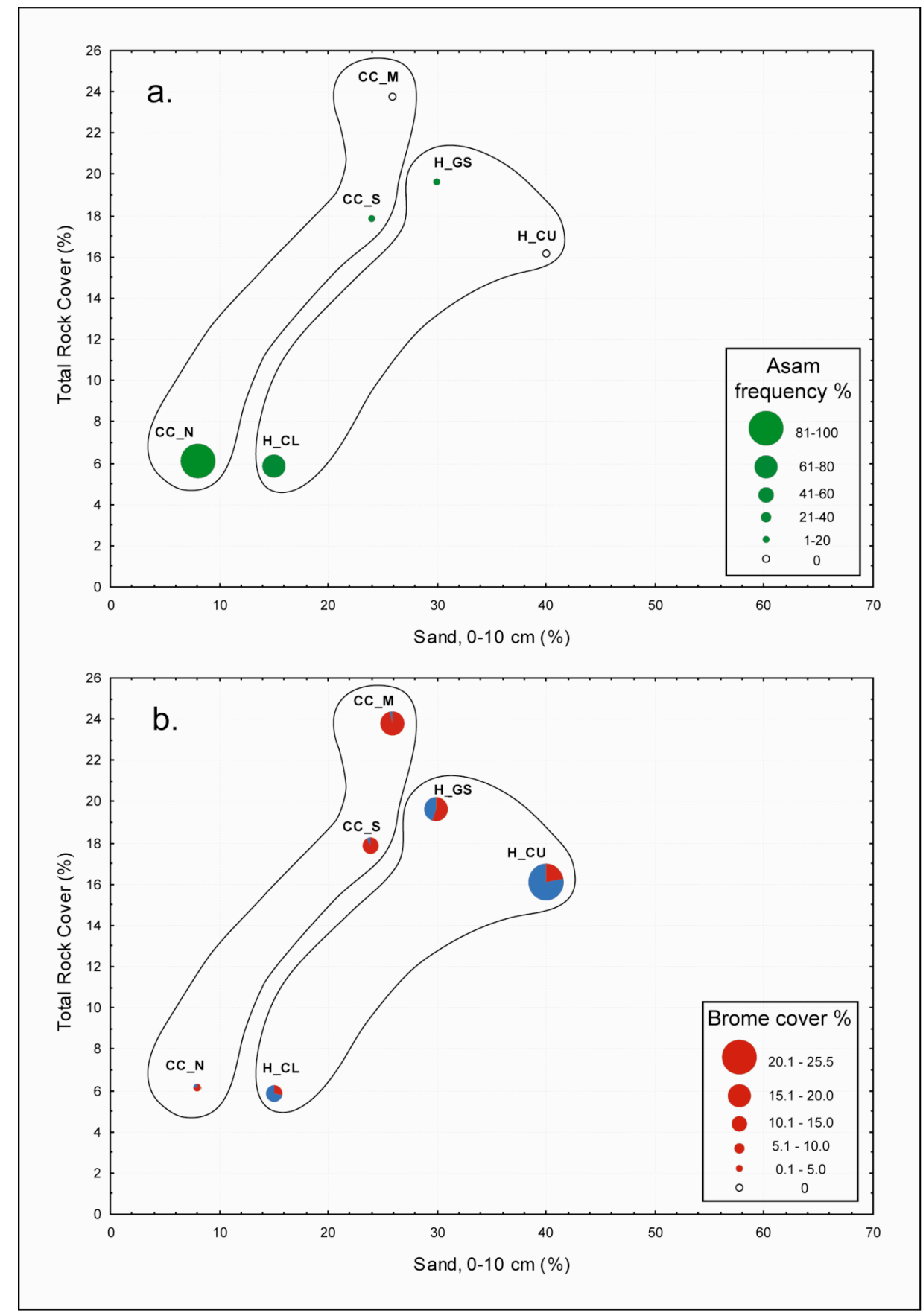

Figure 5. Graphs showing variations in (a) milk-vetch (Asam) frequency and (b) total brome cover in relation to $0-10 \mathrm{~cm}$ sand content and total rock cover at the Coral Canyon (CC) and Harrisburg $(\mathrm{H})$ sites. In (b), relative proportions of red brome and cheatgrass are indicated by red and blue segments of symbols, respectively. See Table 3 for key to plot codes.

\section{On-Going Work and Future Plans}

\section{Habitat Modelling}

We are currently proceeding with efforts to develop a GIS-based predictive habitat model that can be used to guide future surveys and efforts to evaluate sites for reintroduction efforts (Research 
Objective 4, above). Given the small number of known milk-vetch populations and thus the limited availability of plant-environment data, we propose to use simple intersection methods in GIS rather than data-intensive statistical techniques to develop a potential habitat model (Fertig and Thurston 2003). Based on our current understanding of the species' range-wide distributional patterns (with 99 percent of the known occurrences are associated with patchily distributed Petrified Forest Member outcrops), geologic unit will be the most important predictive variable. The complete suite of predictive variables that will be considered will include -

a. Geology — clay-rich substrates (categorical variable)

i. Petrified Forest Member of the Chinle Formation

ii. Dinosaur Canyon Member of the Moenave Formation (above Chinle Formation)

iii. Upper red member (Biek 2003) of Moenkopi Formation (below Chinle Formation)

iv. Quaternary landslide / mass movement deposits near cliff faces where deposits may mantle, armor, or surround geologic units such as the Petrified Forest Member

b. Climate (continuous variables)

i. Elevation

ii. Mean seasonal / annual precipitation (exact variables dependent on availability of data)

iii. Mean seasonal / annual temperature (exact variables dependent on availability of data)

c. Topography (continuous variable)

i. Slope

ii. Topographic heat-load index

iii. Local relief

d. Land cover (categorical variable)

Range-intersection analyses in GIS will be supplemented with soil sampling and analysis. Soil samples will be collected from additional clay-rich substrates (e.g., upper red member of the Moenkopi Formation [Biek 2003]) that occur in close proximity to Petrified Forest Member patches but are not currently known to support the milk-vetch. Characteristics of these soil samples will be compared with those of samples previously collected from known population locations to evaluate whether these other substrates have the potential to support the milk-vetch. Products will include a technical report and GIS / spatial data with metadata that comply with Federal Geographic Data Committee standards.

\section{Experimental Studies of Red Brome Effects on Biological Soil Properties and Milk- Vetch Performance}

In September 2006, we established 62 milk-vetch centered experimental plots at the Zion Hilltop site to investigate effects of red brome on soil properties and milk-vetch performance measures using a neighborhood competition design (Goldberg and Werner 1983). Each circular plot measures $80-\mathrm{cm}$ in diameter and is centered on an individual milk-vetch plant that was used in herbivory studies in spring 2006. Each focal milk-vetch plant is protected from vertebrate herbivores by a circular wire-mesh cage measuring $40-\mathrm{cm}$ diameter by $60-\mathrm{cm}$ tall. Standing-dead aboveground biomass of annual plants (primarily red brome), and aboveground biomass of perennial plants were removed from each plot and weighed. Plots were randomly assigned to one of four seeding treatments (Table 6) intended to establish an experimental gradient in red brome 
biomass, and red brome seeds collected from local Zion populations were added to plots and mixed in the upper 1-2 cm of soil. An automated meteorological station also was installed at the Zion Hilltop site in September 2006 to monitor the size and frequency of precipitation events as well as soil volumetric water content, temperature, and electrical conductivity at 5- and 15 -cm depths in two experimental plots assigned to the "medium" and "none" red-brome seeding treatments.

In spring 2007, neighborhood plots will be revisited and milk-vetch performance will be evaluated on the basis of seedling emergence and survivorship, canopy volume of established focal plants, and by numbers of flowering stems, pods, and seeds produced by focal plants. Seeds will be collected from a subset of plants and seed weight and viability determined in the laboratory. Aboveground biomass of exotics will be harvested from each neighborhood plot, dried, and weighed. To evaluate effects of red brome abundance on mycorrhizal associations of established milk-vetch plants, 12 focal milk-vetch plants (three from each of the four levels of brome abundance) will be randomly selected and their roots collected and stored in a freezer until root colonization by arbuscular-mycorrhizal (AM) fungi is quantified using root-staining procedures (Johnson et al. 1999). (This procedure will result in the mortality of the 12 selected individuals.) Finally, soils also will be collected from 30 of the 62 plots representing the exotic biomass gradient and analyzed for soil enzyme activity and $\mathrm{N}$ mineralization rates.

Table 6. Levels and seeding rates used in applications of red brome seeds to milkvetch centered experimental plots in September 2006.

\begin{tabular}{lc}
\hline Seeding level & Seeding rate $\left(\right.$ seeds $\left.\mathbf{~ m}^{-2}\right)$ \\
\hline High & 5000 \\
Medium & 2500 \\
Low & 1250 \\
None & 0 \\
\hline
\end{tabular}

To further evaluate the potential effects of red brome on the mycorrhizal associations of Shivwits milk-vetch, we also will perform a bait-plant bioassay (to assess densities of mycorrhizal propagules) and AM fungi spore counts (to assess mycorrhizal species composition), following methods described by Johnson and others (1999). Intact soil cores measuring approximately $5 \mathrm{~cm}$ in diameter by $15 \mathrm{~cm}$ deep will be collected from the Zion Hilltop study site at the end of the field experiment in spring 2007. Two cores will be collected from each of 62 experimental plots representing a range of aboveground red brome biomass. One core will be extracted within $10 \mathrm{~cm}$ of the focal milk-vetch plant; the other sample will be collected 40-60 cm away from the focal plant, in an area representative of the plot's overall red brome density / biomass. The cores will be categorized into groups according to levels of red brome biomass observed at the end of the 2007 growing season - high, medium, low, and no red brome - with approximately 15 core pairs per group.

Each of the 124 cores will be split lengthwise so that half of each sample may be used for the baitplant bioassay and the other half for AM spore counts. Soil samples for bait-plant studies will be transported in cone-pots to the native plant nursery at Zion NP. Two cores from each red-brome abundance level will be planted with pre-germinated seed of Shivwits milk-vetch and the remaining cores will be planted with pre-germinated seed of Zea mays (corn). Both species will be used because $Z$. mays is known to be a reliable host plant, and nothing yet is known about mycorrhizal relations of the milk-vetch. Plants will be harvested after 6 weeks of growth, and roots will be collected and stored in a freezer until root colonization by AM fungi is quantified using root- 
staining procedures (Johnson et al. 1999). Roots and shoots of milk-vetch plants also will be dried and weighed to evaluate variation in relation to different levels of red brome biomass and (potentially) different levels of AM fungi colonization.

Soil samples for AM spore counts will be homogenized and kept frozen until analyses are preformed at Northern Arizona University (NAU) in fall of 2007. Spores will be extracted from the soil samples through a process of centrifuging and vacuum filtration, then dyed and quantified using a compound microscope (Johnson et al. 1999).

\section{Literature Cited}

Biek, R.F. 2003. Geologic map of the Harrisburg Junction Quadrangle, Washington County, Utah. Utah Geological Survey Map 191, 42 p., map scale 1:24,000.

Biek, R.F., G.C. Willis, M.D. Hylland, and H.H. Doelling. 2000. Geology of Zion National Park, Utah. Pages 107-138 in D.A. Sprinkel, T.C. Chidsey, Jr., and P.B. Anderson, eds. Geology of Utah's Parks and Monuments, 2000 Utah Geological Association Publication 28, Millenium Guidebook. Utah Geological Association, Salt Lake City.

Fertig, W., and R. Thurston. 2003. Modeling the potential distribution of BLM sensitive and USFWS threatened and endangered plant species in Wyoming. Report to the Bureau of Land Management, Wyoming State Office, by the Wyoming Natural Diversity Database, University of Wyoming, Laramie. 44 pp. + appendices.

Goldberg, D. E., and P. A. Werner. 1983. Equivalence of competitors in plant communities: A null hypothesis and a field experimental approach. American Journal of Botany 70: 1098-1104.

Harper, J. L. 1977. Population biology of plants. Academic Press, San Diego.

Harper, J. L., J. T. Williams, and G. R. Sagar. 1965. The behaviour of seeds in soil. I. The heterogeneity of soil surfaces and its role in determining the establishment of plants from seed. Journal of Ecology 53: 273-286.

Hintze, L.F., and B.J. Hammond. 1994. Geologic map of the Shivwits Quadrangle, Washington County, Utah. Utah Geological Survey Map 153, 21 p., map scale 1:24,000.

Ingram, R.L. 1982. Modified Wentworth scale. In: Grain-size scales. AGI Data Sheet 29.1. In: Dutro, J.T., R.V. Dietrich, and R.M. Foose. 1989. AGI data sheets for geology in the field, laboratory, and office, $3^{\text {rd }}$ edition. American Geological Institute, Washington, D.C.

Johnson, N. C., T. E. O'Dell, and C. S. Bledsoe. 1999. Methods for ecological studies of mycorrhizae. Pages 378-412 in G. P. Robertson, D. C. Coleman, C. S. Bledsoe, and P. Sollins, eds. Standard soil methods for long-term ecological research. Oxford University Press, New York.

McCune, B. P., and J. B. Grace. 2002. Analysis of ecological communities. MJM Software Design, Gleneden Beach, Oregon.

McCune, B. P., and D. Keon. 2002. Equations for potential annual direct incident radiation and heat load. Journal of Vegetation Science 13: 603-606.

McCune, B. and M. J. Mefford. 1999. PC-ORD - multivariate analysis of ecological data, version 4.3. MjM Software, Gleneden Beach, Oregon, U.S.A., http://www.pcord.com.

Noy-Meir, I. 1973. Desert ecosystems: Environment and producers. Annual Review of Ecology and Systematics 4: 25-51. 
StatSoft, Inc. 2004. STATISTICA (data analysis software system), version 6.1. www.statsoft.com.

Tepedino, V. J. 2005. Reproduction and pollination of two rare species of Astragalus from Washington County, southern Utah: A. holmgreniorum and A. ampullarioides. USDAARS Bee Biology and Systematics Laboratory, Department of Biology, Utah State University, Logan, UT. 18 pp.

U.S. Fish and Wildlife Service. 2001. Endangered and threatened wildlife and plants; Determination of endangered status for Astagalus holmgreniorum (Holmgren milk-vetch) and Astragalus ampullarioides (Shivwits milk-vetch). Federal Register 66 (189): 4956049567.

U.S. Fish and Wildlife Service. 2006. Astragalus holmgreniorum (Holmgren Milk-Vetch) and Astragalus ampullarioides (Shivwits Milk-Vetch) recovery plan. U.S. Department of Interior, Fish and Wildlife Service, Denver, CO. 114 pp. [Available online at http://www.fws.gov/endangered/recovery/]

Van Buren, R., and K. T. Harper. 2003. Demographic and environmental relations of two rare Astragalus species endemic to Washington County, Utah: Astragalus holmgreniorum and A. ampullarioides. Western North American Naturalist 63: 236-243.

Welsh, S. L., N. D. Atwood, S. Goodrich, and L. C. Higgins, eds. 2003. A Utah flora. Third edition, revised. Brigham Young University, Provo, Utah. 912 p.

Willis, G.C., H.H. Doelling, B.J. Solomon, and E.G. Sable. 2002. Interim geologic map of the Springdale West Quadrangle, Washington County, Utah. Utah Geologic Survey Open-File Report 394, 20 p., map scale :24,000. 


\section{Appendix A - Map of Plot Locations}

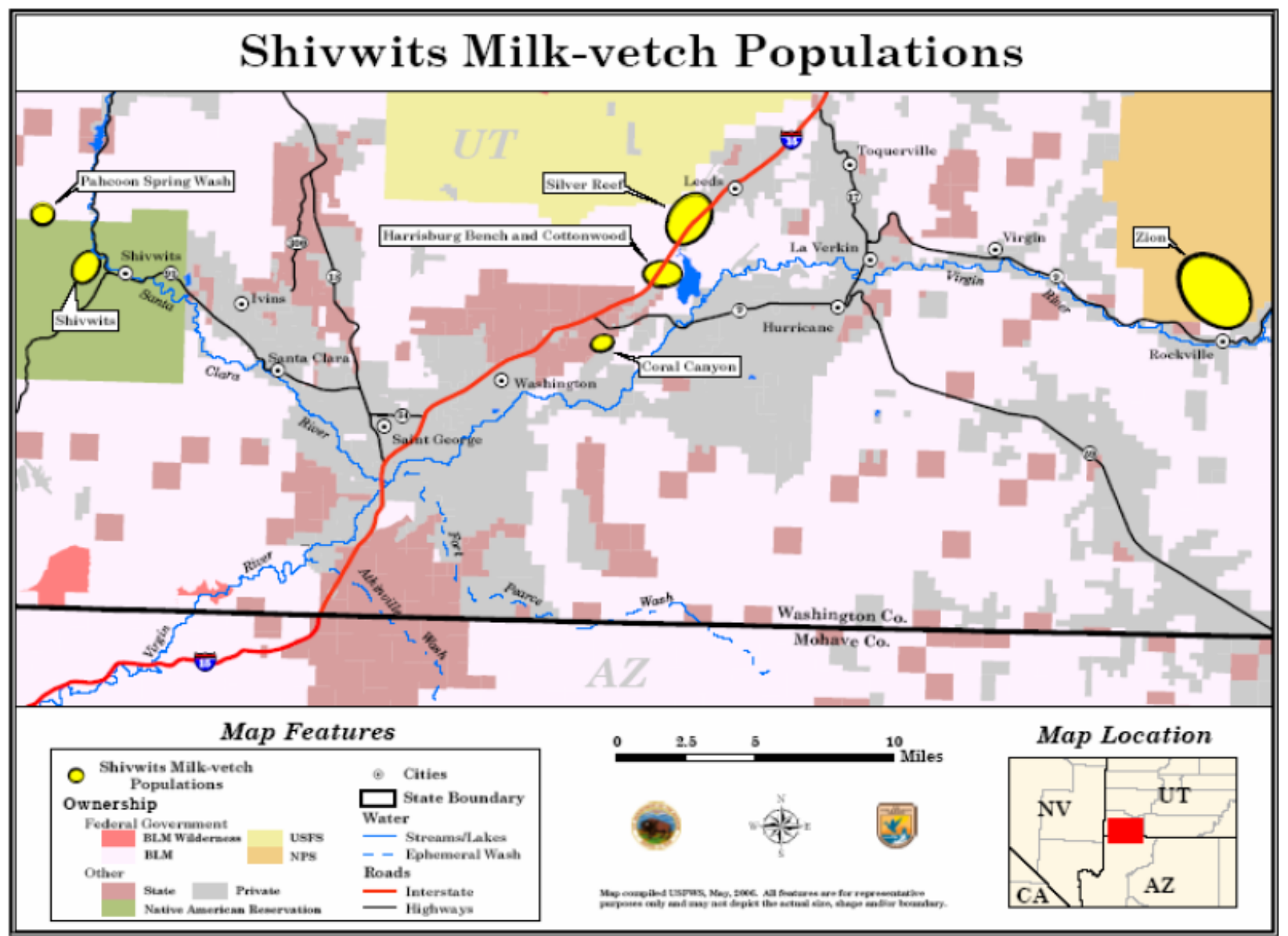

Figure A1. General locations of six Shivwits milk-vetch populations in Washington County, Utah (from USFWS 2006). 


\section{Appendix B - Graphs for Herbivory Experiment}

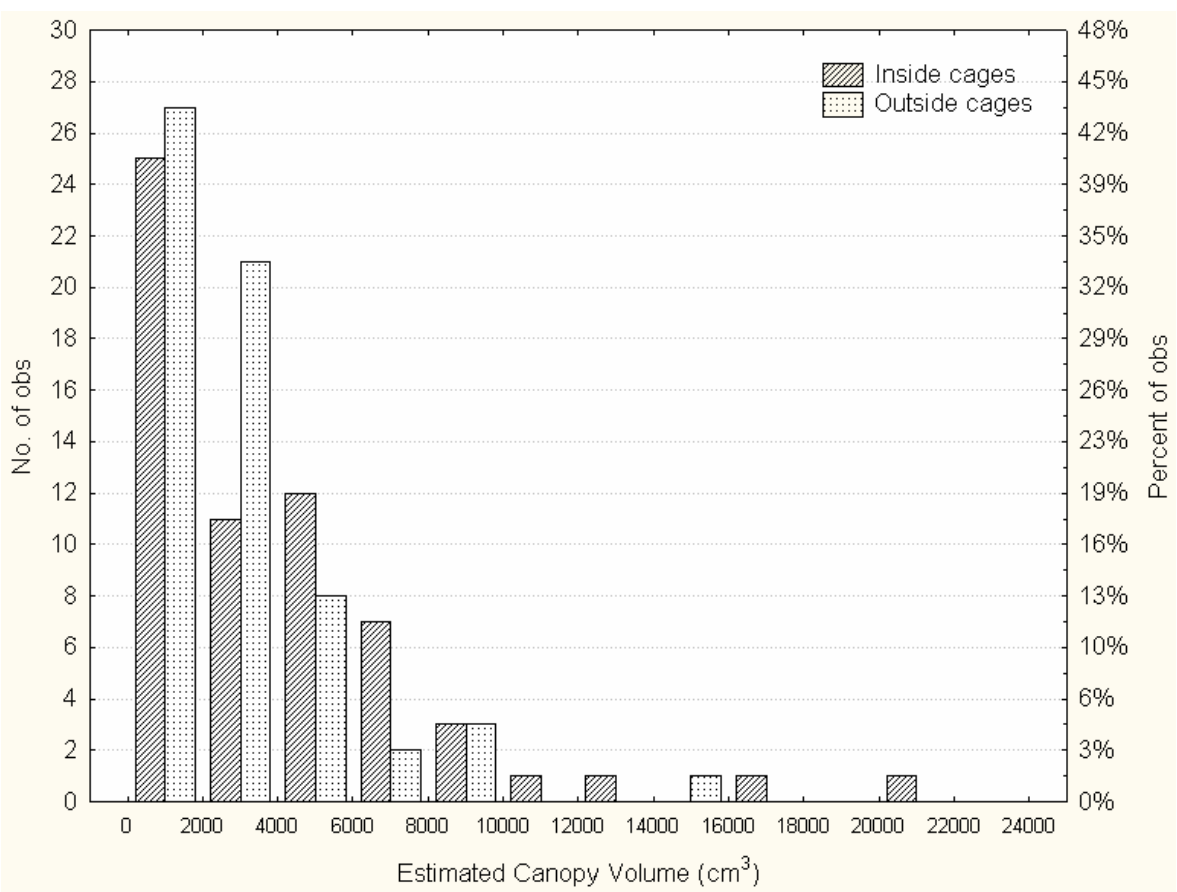

Figure B1. Histogram for estimated canopy volume of milk-vetch plants inside and outside of herbivore-exclusion cages at the Zion Hilltop site, spring 2006.

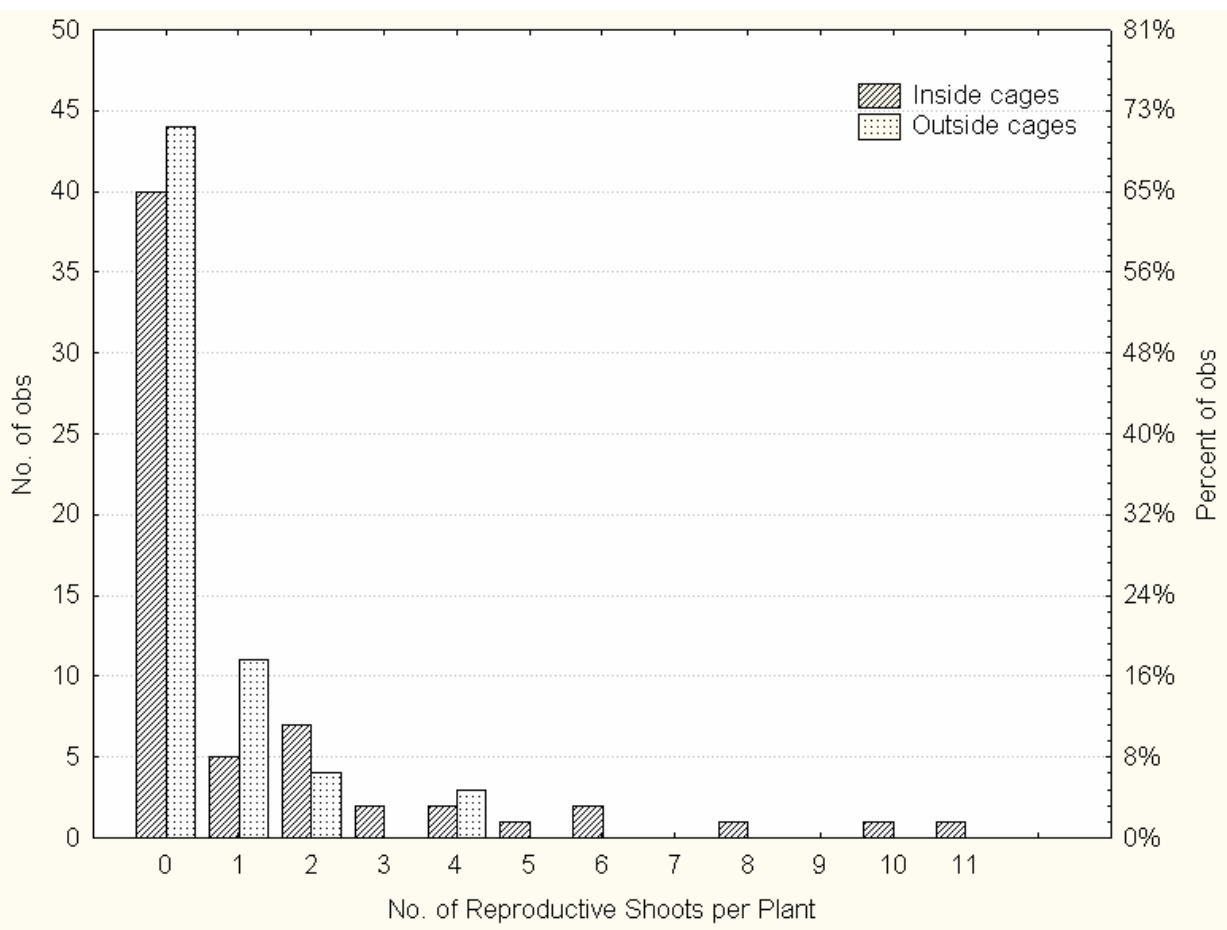

Figure B2. Histogram for the number of reproductive shoots produced by milk-vetch plants inside and outside of herbivore-exclusion cages at the Zion Hilltop site, spring 2006. 


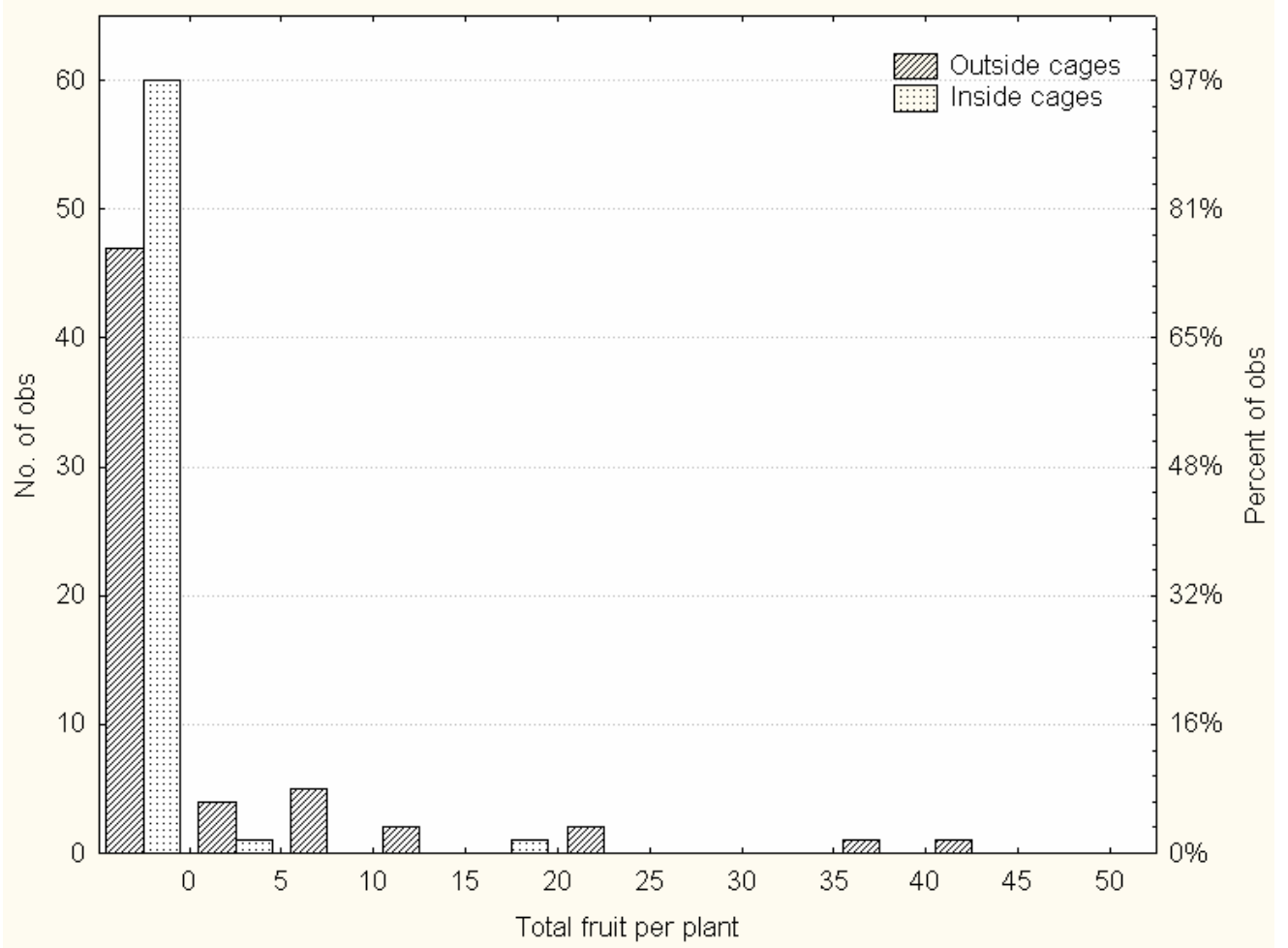

Figure B3. Histogram for the total number of fruit produced by milk-vetch plants inside and outside of herbivore-exclusion cages at the Zion Hilltop site, spring 2006. 


\section{Appendix C - Plot-Level Quadrat data}


Table C1. Mean cover, frequency, and density data for Zion Hilltop soil-vegetation plots CORA1, CORA2, and Asam Lo1.

\begin{tabular}{|c|c|c|c|c|c|c|}
\hline & \multicolumn{2}{|c|}{$\begin{array}{c}\text { Zion } \\
\text { CORA } 1 \\
4 \text { transects } \\
12 \text { quadrats }\end{array}$} & \multicolumn{2}{|c|}{$\begin{array}{c}\text { Zion } \\
\text { CORA } 2 \\
4 \text { transects } \\
12 \text { quadrats }\end{array}$} & \multicolumn{2}{|c|}{$\begin{array}{c}\text { Zion } \\
\text { Asam Lo1 } \\
4 \text { transects } \\
12 \text { quadrats }\end{array}$} \\
\hline & Cover & $1-m^{2}$ freq & Cover & $1-m^{2}$ freq & Cover & $1-m^{2}$ freq \\
\hline \multicolumn{7}{|l|}{ Perennial forbs } \\
\hline Allium nevadense & 0.3 & 25.0 & 0.3 & 25.0 & 0.1 & 8.3 \\
\hline Astragalus ampullarioides & 0.1 & 8.3 & 0.1 & 8.3 & 0.2 & 8.3 \\
\hline Eriogonum inflatum & 0.1 & 8.3 & - & - & - & - \\
\hline Zigadenus paniculatus & - & - & 0.3 & 25.0 & - & - \\
\hline \multicolumn{7}{|l|}{ Annual forbs } \\
\hline Eriogonum subreniforme & 0.1 & 8.3 & 0.2 & 16.7 & 0.1 & 8.3 \\
\hline Euphorbia spathulata & - & - & - & - & 0.1 & 8.3 \\
\hline Lactuca serriola* & - & - & - & - & 0.5 & 50.0 \\
\hline Moluccella laevis* & - & - & - & - & 0.9 & 91.7 \\
\hline Zion_AF2 & 0.3 & 25.0 & 0.5 & 50.0 & - & - \\
\hline Zion_AF3 & 0.1 & 8.3 & - & - & - & - \\
\hline Zion_AF6 & - & - & 0.3 & 33.3 & - & - \\
\hline Zion_AF7 & - & - & 0.1 & 8.3 & - & - \\
\hline \multicolumn{7}{|l|}{ Perennial grasses } \\
\hline Elymus elymoides & - & - & 0.1 & 8.3 & - & - \\
\hline Hilaria jamesii & 0.3 & 8.3 & 0.5 & 33.3 & 0.3 & 8.3 \\
\hline \multicolumn{7}{|l|}{ Annual grasses } \\
\hline Bromus rubens* & 3.6 & 100.0 & 9.9 & 100.0 & 12.6 & 100.0 \\
\hline Bromus tectorum* & 0.1 & 8.3 & - & - & 0.3 & 33.3 \\
\hline Bromus, standing dead & 2.5 & 100.0 & 9.5 & 100.0 & 23.2 & 100.0 \\
\hline \multicolumn{7}{|l|}{ Shrubs / subshrubs } \\
\hline Atriplex canescens & - & - & 3.7 & 25.0 & 0.7 & 16.7 \\
\hline Chrysothamnus nauseosus & 0.8 & 8.3 & - & - & - & - \\
\hline Chrysothamnus viscidiflorus & - & - & - & - & 0.1 & 8.3 \\
\hline Coleogyne ramosissima & 5.9 & 83.3 & 5.4 & 66.7 & - & - \\
\hline Ephedra viridis & 1.5 & 33.3 & - & - & - & - \\
\hline Gutierrezia microcephala & - & - & 0.4 & 33.3 & 0.1 & 8.3 \\
\hline Psorothamnus fremontii & 0.2 & 8.3 & 3.3 & 16.7 & - & - \\
\hline \multicolumn{7}{|l|}{ Summary, vascular plants } \\
\hline Total live vascular cover & 13.2 & & 25.0 & & 15.8 & \\
\hline Total native cover & 9.5 & & 15.1 & & 1.5 & \\
\hline Total exotic cover & 3.7 & & 9.9 & & 14.3 & \\
\hline Relative native cover & 75.0 & & 66.4 & & 7.7 & \\
\hline Relative exotic cover & 25.0 & & 33.6 & & 92.3 & \\
\hline Total richness & 13 & & 14 & & 12 & \\
\hline Native richness & 11 & & 13 & & 8 & \\
\hline Exotic richness & 2 & & 1 & & 4 & \\
\hline \multicolumn{7}{|l|}{ Soil-surface features } \\
\hline Rabbit Dung (freq only) & & 83.3 & & 83.3 & & 83.3 \\
\hline Litter & 5.8 & 100.0 & 33.0 & 100.0 & 34.2 & 100.0 \\
\hline Woody debris & 0.6 & 50.0 & 0.1 & 8.3 & 0.2 & 16.7 \\
\hline Small Rock $(<20$ mm) & 4.2 & 100.0 & 1.8 & 91.7 & 2.0 & 100.0 \\
\hline Large Rock (> 20 mm) & 1.0 & 33.3 & 0.2 & 16.7 & 0.1 & 8.3 \\
\hline Total Rock & 5.2 & 100.0 & 2.0 & 91.7 & 2.1 & 100.0 \\
\hline Cyanobacterial crust & 0.1 & 8.3 & 0.2 & 8.3 & - & - \\
\hline Lichen crust & - & - & - & - & - & - \\
\hline Moss crust & 0.2 & 8.3 & 0.6 & 25.0 & - & - \\
\hline Physical crust & 66.6 & 100.0 & 51.3 & 91.7 & 53.3 & 91.7 \\
\hline Loose, unstable soil & 5.9 & 83.3 & 3.6 & 50.0 & 0.1 & 8.3 \\
\hline Piping (freq only) & & - & & - & & 50.0 \\
\hline $\begin{array}{l}\text { Density by height class } \\
\text { Astragalus ampullarioides }\end{array}$ & Count & Per $\mathrm{m}^{2}$ & Count & Per $\mathrm{m}^{2}$ & Count & Per $\mathrm{m}^{2}$ \\
\hline $0.1-4 \mathrm{~cm}$ & - & - & - & - & - & - \\
\hline $5-12 \mathrm{~cm}$ & 1 & 0.1 & 1 & 0.1 & 1 & 0.1 \\
\hline$>12 \mathrm{~cm}$ & - & - & - & - & - & - \\
\hline$>12 \mathrm{~cm}$, flowering & - & - & - & - & 1 & 0.1 \\
\hline Total & 1 & 0.1 & 1 & 0.1 & 2 & 0.2 \\
\hline \multicolumn{7}{|l|}{ Moluccella laevis* } \\
\hline $0.1-4 \mathrm{~cm}$ & - & - & - & - & 259 & 21.6 \\
\hline
\end{tabular}


Table C2. Mean cover, frequency, and density data for Zion Hilltop soil-vegetation plots Asam Hi1, Asam Hi2, and Asam Hi3.

\begin{tabular}{|c|c|c|c|c|c|c|}
\hline & \multicolumn{2}{|c|}{$\begin{array}{c}\text { Zion } \\
\text { Asam Hi1 } \\
4 \text { transects } \\
12 \text { quadrats }\end{array}$} & \multicolumn{2}{|c|}{$\begin{array}{c}\text { Zion } \\
\text { Asam Hi2 } \\
4 \text { transects } \\
12 \text { quadrats }\end{array}$} & \multicolumn{2}{|c|}{$\begin{array}{c}\text { Zion } \\
\text { Asam Hi3 } \\
4 \text { transects } \\
12 \text { quadrats }\end{array}$} \\
\hline & Cover & $1-m^{2}$ freq & Cover & $1-m^{2}$ freq & Cover & $1-m^{2}$ freq \\
\hline \multicolumn{7}{|l|}{ Perennial forbs } \\
\hline Allium nevadense & 0.3 & 25.0 & 0.3 & 33.3 & 0.1 & 8.3 \\
\hline Astragalus ampullarioides & 2.0 & 91.7 & 1.7 & 83.3 & 1.3 & 83.3 \\
\hline Delphinium sp. & 0.6 & 58.3 & 0.2 & 16.7 & - & - \\
\hline Sphaeralcea sp. & - & - & - & - & 0.1 & 8.3 \\
\hline Zion_PF1 & 0.1 & 8.3 & - & - & - & - \\
\hline \multicolumn{7}{|l|}{ Annual forbs } \\
\hline Erodium cicutarium* & 0.1 & 8.3 & 0.2 & 16.7 & 0.2 & 16.7 \\
\hline Euphorbia spathulata & 0.2 & 16.7 & 0.4 & 41.7 & 0.1 & 8.3 \\
\hline Lactuca serriola* & 0.2 & 16.7 & 0.1 & 8.3 & 0.2 & 16.7 \\
\hline Moluccella laevis* & 0.5 & 50.0 & 0.3 & 25.0 & 0.3 & 33.3 \\
\hline Phacelia sp. & - & - & 0.3 & 25.0 & - & - \\
\hline Zion_AF3 & 0.1 & 8.3 & - & - & - & - \\
\hline \multicolumn{7}{|l|}{ Perennial grasses } \\
\hline Elymus elymoides & 0.2 & 16.7 & 0.3 & 25.0 & 0.4 & 33.3 \\
\hline Hilaria jamesii & 4.6 & 100.0 & 1.3 & 58.3 & 0.3 & 25.0 \\
\hline \multicolumn{7}{|l|}{ Annual grasses } \\
\hline Bromus rubens* & 8.2 & 100.0 & 12.3 & 100.0 & 15.8 & 100.0 \\
\hline Bromus tectorum* & 0.3 & 16.7 & - & - & 0.1 & 8.3 \\
\hline Bromus, standing dead & 14.8 & 100.0 & 16.4 & 100.0 & 29.7 & 100.0 \\
\hline \multicolumn{7}{|l|}{ Shrubs / subshrubs } \\
\hline Atriplex canescens & 1.5 & 25.0 & 2.5 & 25.0 & 2.0 & 41.7 \\
\hline Gutierrezia microcephala & 0.1 & 8.3 & 0.3 & 25.0 & 0.1 & 8.3 \\
\hline \multicolumn{7}{|l|}{ Summary, vascular plants } \\
\hline Total live vascular cover & 18.8 & & 19.8 & & 20.8 & \\
\hline Total native cover & 9.5 & & 7.1 & & 4.3 & \\
\hline Total exotic cover & 9.3 & & 12.8 & & 16.5 & \\
\hline Relative native cover & 50.6 & & 35.0 & & 20.0 & \\
\hline Relative exotic cover & 49.4 & & 65.0 & & 80.0 & \\
\hline Total richness & 15 & & 13 & & 13 & \\
\hline Native richness & 10 & & 9 & & 8 & \\
\hline Exotic richness & 5 & & 4 & & 5 & \\
\hline \multicolumn{7}{|l|}{ Soil-surface features } \\
\hline Rabbit Dung (freq only) & & 91.7 & & 100.0 & & 75.0 \\
\hline Litter & 30.2 & 100.0 & 28.8 & 100.0 & 44.8 & 100.0 \\
\hline Woody debris & 0.1 & 8.3 & 0.3 & 25.0 & 0.1 & 8.3 \\
\hline Small Rock $(<20$ mm) & 3.3 & 100.0 & 2.8 & 100.0 & 1.5 & 100.0 \\
\hline Large Rock (> $20 \mathrm{~mm}$ ) & 0.3 & 25.0 & 0.2 & 16.7 & 0.1 & 8.3 \\
\hline Total Rock & 3.7 & 100.0 & 3.0 & 100.0 & 1.6 & 100.0 \\
\hline Cyanobacterial crust & - & - & - & - & - & - \\
\hline Lichen crust & - & - & - & - & - & - \\
\hline Moss crust & - & - & - & - & - & - \\
\hline Physical crust & 52.1 & 100.0 & 59.2 & 100.0 & 44.6 & 100.0 \\
\hline Loose, unstable soil & 0.3 & 16.7 & 0.3 & 16.7 & - & - \\
\hline Piping (freq only) & & - & & - & & 16.7 \\
\hline $\begin{array}{l}\text { Density by height class } \\
\text { Astragalus ampullarioides }\end{array}$ & Count & Per $\mathrm{m}^{2}$ & Count & Per $\mathrm{m}^{2}$ & Count & Per $\mathrm{m}^{2}$ \\
\hline $0.1-4 \mathrm{~cm}$ & 7 & 0.6 & 15 & 1.3 & 26 & 2.2 \\
\hline $5-12 \mathrm{~cm}$ & 21 & 1.8 & 21 & 1.8 & 10 & 0.8 \\
\hline$>12 \mathrm{~cm}$ & 6 & 0.5 & 3 & 0.3 & - & - \\
\hline$>12 \mathrm{~cm}$, flowering & - & - & 2 & 0.2 & 3 & 0.3 \\
\hline Total & 34 & 2.8 & 41 & 3.4 & 39 & 3.3 \\
\hline \multicolumn{7}{|l|}{ Moluccella laevis* } \\
\hline $0.1-4 \mathrm{~cm}$ & 15 & 1.3 & 7 & 0.6 & 4 & 0.3 \\
\hline $5-12 \mathrm{~cm}$ & - & - & 2 & 0.2 & - & - \\
\hline$>12 \mathrm{~cm}$ & - & - & - & - & - & - \\
\hline$>12 \mathrm{~cm}$, flowering & 1 & 0.1 & - & - & - & - \\
\hline Total & 16 & 1.3 & 9 & 0.8 & 4 & 0.3 \\
\hline
\end{tabular}


Table C3. Mean cover, frequency, and density data for soil-vegetation plots at the Zion Petrified Forest and Trailside sites.

\begin{tabular}{|c|c|c|c|c|c|c|c|c|}
\hline & \multicolumn{2}{|c|}{$\begin{array}{r}\text { Zion } \\
\text { Petrified Forest } \\
3 \text { transects } \\
18 \text { quadrats }\end{array}$} & \multicolumn{2}{|c|}{$\begin{array}{c}\text { Zion } \\
\text { Trail North } \\
3 \text { transects } \\
17 \text { quadrats }\end{array}$} & \multicolumn{2}{|c|}{$\begin{array}{c}\text { Zion } \\
\text { Trail SAVE } \\
3 \text { transects } \\
12 \text { quadrats }\end{array}$} & \multicolumn{2}{|c|}{$\begin{array}{c}\text { Zion } \\
\text { Trail South } \\
2 \text { transects } \\
16 \text { quadrats }\end{array}$} \\
\hline & Cover & $1-m^{2}$ freq & Cover & $1-m^{2}$ freq & Cover & $1-m^{2}$ freq & Cover & $1-m^{2}$ freq \\
\hline \multicolumn{9}{|l|}{ Perennial forbs } \\
\hline Allium nevadense & - & - & 0.4 & 35.3 & 0.1 & 8.3 & 0.2 & 18.8 \\
\hline Astragalus ampullarioides & 0.1 & 11.1 & 1.1 & 70.6 & 0.8 & 50.0 & 0.4 & 31.3 \\
\hline Astragalus flavus & 0.1 & 5.6 & 0.7 & 41.2 & - & - & - & - \\
\hline Cymopterus purpureus & 0.1 & 11.1 & 0.1 & 5.9 & - & - & - & . \\
\hline Zigadenus paniculatus & - & - & 0.1 & 11.8 & - & - & - & - \\
\hline \multicolumn{9}{|l|}{ Annual forbs } \\
\hline Chenopodium sp. & - & - & 0.1 & 11.8 & - & - & - & . \\
\hline Eriogonum subreniforme & - & - & - & - & - & - & 0.1 & 12.5 \\
\hline Euphorbia spathulata & - & - & - & - & - & - & 0.1 & 6.3 \\
\hline Lactuca serriola* & - & - & - & - & - & - & 0.3 & 31.3 \\
\hline Lappula occidentalis & - & - & - & - & - & - & 0.1 & 6.3 \\
\hline Layia glandulosa & 0.1 & 11.1 & - & - & - & - & - & . \\
\hline Moluccella laevis* & - & - & - & - & 0.1 & 8.3 & 0.7 & 68.8 \\
\hline Plantago patagonica & 1.0 & 77.8 & - & - & - & - & - & . \\
\hline Salvia columbariae & - & - & - & - & - & - & 0.2 & 18.8 \\
\hline Viguiera longifolia & - & - & 0.5 & 52.9 & 0.3 & 33.3 & 0.9 & 93.8 \\
\hline Zion_AF8 & 0.8 & 83.3 & - & - & - & - & - & 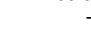 \\
\hline \multicolumn{9}{|l|}{ Perennial grasses } \\
\hline Distichlis spicata & - & - & - & - & 0.1 & 8.3 & - & . \\
\hline Elymus elymoides & 0.2 & 16.7 & 0.2 & 17.6 & 0.1 & 8.3 & 0.1 & 6.3 \\
\hline Hilaria jamesii & 3.6 & 88.9 & 3.5 & 64.7 & 0.3 & 8.3 & 1.9 & 50.0 \\
\hline Stipa hymenoides & 0.1 & 11.1 & - & - & 0.1 & 8.3 & - & . \\
\hline Sporobolus airoides & 0.7 & 22.2 & - & - & - & - & - & - \\
\hline \multicolumn{9}{|l|}{ Annual grasses } \\
\hline Bromus rubens* & 4.1 & 100.0 & 5.6 & 100.0 & 4.0 & 100.0 & 1.8 & 100.0 \\
\hline Bromus tectorum* & 1.6 & 44.4 & - & - & - & - & 0.7 & 68.8 \\
\hline Bromus, standing dead & 4.6 & & 6.9 & 100.0 & 14.0 & 100.0 & 1.6 & 56.3 \\
\hline Shrubs / subshrubs & & & & & & & & \\
\hline Artemisia tridentata var. wyom. & 1.2 & 33.3 & - & - & - & - & - & . \\
\hline Atriplex canescens & - & - & - & - & 0.2 & 8.3 & - & . \\
\hline Atriplex confertifolia & - & - & - & - & 0.2 & 8.3 & - & . \\
\hline Chrysothamnus nauseosus & 0.3 & 16.7 & 0.5 & 23.5 & 1.7 & 66.7 & 0.3 & 25.0 \\
\hline Chrysothamnus viscidiflorus & - & - & - & - & - & - & - & . \\
\hline Coleogyne ramosissima & - & - & 0.6 & 23.5 & - & - & 2.6 & 12.5 \\
\hline Ephedra nevadensis & - & - & 0.1 & 5.9 & - & - & - & . \\
\hline Gutierrezia microcephala & - & - & 0.9 & 47.1 & - & - & - & . \\
\hline Gutierrezia sarothrae & 1.2 & 72.2 & - & - & - & - & - & . \\
\hline Psorothamnus fremontii & - & - & 0.1 & 5.9 & - & - & - & - \\
\hline Trees & & & & & & & & \\
\hline Juniperus osteosperma & 4.2 & 5.6 & - & - & 6.3 & 25.0 & 0.8 & 6.3 \\
\hline Summary, vascular plants & & & & & & & & \\
\hline Total live vascular cover & 19.3 & & 14.5 & & 14.1 & & 11.0 & \\
\hline Total native cover & 13.7 & & 8.9 & & 10.0 & & 7.6 & \\
\hline Total exotic cover & 5.6 & & 5.6 & & 4.1 & & 3.4 & \\
\hline Relative native cover & 69.3 & & 59.7 & & 47.4 & & 57.0 & \\
\hline Relative exotic cover & 30.7 & & 40.3 & & 52.6 & & 43.0 & \\
\hline Total richness & 16 & & 15 & & 13 & & 16 & \\
\hline Native richness & 14 & & 14 & & 11 & & 12 & \\
\hline Exotic richness & 2 & & 1 & & 2 & & 4 & \\
\hline Soil-surface features & & & & & & & & \\
\hline Rabbit Dung (freq only) & & 88.9 & & 82.4 & & 41.7 & & 81.3 \\
\hline Litter & 25.1 & 100.0 & 16.2 & 100.0 & 27.1 & 91.7 & 6.2 & 93.8 \\
\hline Woody debris & 0.4 & 27.8 & - & - & - & - & 0.4 & 43.8 \\
\hline Small Rock (<20 mm) & 0.7 & 55.6 & 8.6 & 100.0 & 13.0 & 100.0 & 4.3 & 87.5 \\
\hline Large Rock (> $20 \mathrm{~mm}$ ) & 1.6 & 27.8 & 0.2 & 11.8 & - & - & 0.4 & 12.5 \\
\hline Total Rock & 2.3 & 61.1 & 8.8 & 100.0 & 13.0 & 100.0 & 4.6 & 87.5 \\
\hline Nostoc (vagrant cyanobacteria) & - & - & 0.1 & 5.9 & - & - & - & . \\
\hline Cyanobacterial crust & 0.8 & 22.2 & - & - & - & - & - & . \\
\hline Lichen crust & 0.1 & 5.6 & - & - & - & - & - & . \\
\hline Moss crust & 0.1 & 11.1 & 0.2 & 11.8 & - & - & - & . \\
\hline Physical crust & 56.9 & 94.4 & 65.3 & 100.0 & 47.1 & 100.0 & 78.8 & 100.0 \\
\hline Loose, unstable soil & 0.6 & 27.8 & 1.9 & 70.6 & 2.4 & 41.7 & 6.0 & 100.0 \\
\hline Piping (freq only) & & - & & 35.3 & & 33.3 & & 25.0 \\
\hline $\begin{array}{l}\text { Density by height class } \\
\text { Astragalus ampullarioides }\end{array}$ & Count & per m2 & Count & per m2 & Count & per m2 & Count & per $\mathrm{m} 2$ \\
\hline $0.1-4 \mathrm{~cm}$ & - & - & 2 & 0.1 & 3 & 0.3 & 1 & 0.1 \\
\hline $5-12 \mathrm{~cm}$ & 2 & 0.11 & 25 & 1.5 & 16 & 1.3 & 5 & 0.3 \\
\hline$>12 \mathrm{~cm}$ & 1 & 0.06 & 4 & 0.2 & - & - & - & . \\
\hline$>12 \mathrm{~cm}$, flowering & - & - & 4 & 0.2 & 2 & 0.2 & - & . \\
\hline Total & 3 & 0.17 & 35 & 2.1 & 21 & 1.8 & 6 & 0.4 \\
\hline Moluccella laevis* & & & & & & & & \\
\hline $0.1-4 \mathrm{~cm}$ & - & - & - & - & 6 & 0.5 & 54 & 4.5 \\
\hline
\end{tabular}


Table C4. Mean cover, frequency, and density data for Coral Canyon soil-vegetation plots.

\begin{tabular}{|c|c|c|c|c|c|c|}
\hline & \multicolumn{2}{|c|}{$\begin{array}{c}\text { Coral Canyon } \\
\text { North } \\
4 \text { transects } \\
12 \text { quadrats }\end{array}$} & \multicolumn{2}{|c|}{$\begin{array}{l}\text { Coral Canyon } \\
\text { Middle } \\
4 \text { transects } \\
12 \text { quadrats }\end{array}$} & \multicolumn{2}{|c|}{$\begin{array}{l}\text { Coral Canyon } \\
\text { South } \\
2 \text { transects } \\
12 \text { quadrats }\end{array}$} \\
\hline & Cover & 1- $\mathrm{m}^{2}$ freq & Cover & 1- $\mathrm{m}^{2}$ freq & Cover & 1- $m^{2}$ freq \\
\hline \multicolumn{7}{|l|}{ Perennial forbs } \\
\hline Allium nevadense & - & - & 0.1 & 8.3 & 0.1 & 8.3 \\
\hline Astragalus ampullarioides & 0.9 & 91.7 & - & - & 0.2 & 16.7 \\
\hline Eriogonum inflatum & - & - & - & - & 0.1 & 8.3 \\
\hline Sphaeralcea sp. & - & - & 0.3 & 8.3 & 1.1 & 41.7 \\
\hline \multicolumn{7}{|l|}{ Annual forbs } \\
\hline Astragalus sp. & - & - & - & - & 0.3 & 25.0 \\
\hline Chenopodium sp. & - & - & 0.1 & 8.3 & 0.2 & 8.3 \\
\hline Erodium cicutarium* & 0.8 & 75.0 & 0.2 & 16.7 & 0.7 & 66.7 \\
\hline Lappula occidentalis & 0.1 & 8.3 & - & - & - & - \\
\hline Lotus humistratus & 0.2 & 16.7 & - & - & - & - \\
\hline Plantago patagonica & - & - & - & - & 0.5 & 50.0 \\
\hline Salsola sp.* & 0.2 & 16.7 & - & - & - & - \\
\hline Salvia sp. & 0.3 & 33.3 & - & - & - & - \\
\hline Coral_AF1 & 0.1 & 8.3 & - & - & - & - \\
\hline \multicolumn{7}{|l|}{ Perennial grasses } \\
\hline Hilaria rigida & 0.9 & 25.0 & 3.0 & 41.7 & - & - \\
\hline \multicolumn{7}{|l|}{ Annual grasses } \\
\hline Bromus rubens* & 2.7 & 100.0 & 19.0 & 100.0 & 11.7 & 100.0 \\
\hline Bromus tectorum* & 0.9 & 83.3 & 0.6 & 50.0 & 1.0 & 100.0 \\
\hline Bromus, standing dead & 2.1 & 91.7 & 10.1 & 100.0 & 5.6 & 100.0 \\
\hline Hordeum sp.* & - & - & - & - & 0.4 & 41.7 \\
\hline \multicolumn{7}{|l|}{ Shrubs / subshrubs } \\
\hline Gutierrezia microcephala & 2.3 & 83.3 & 0.6 & 41.7 & 0.8 & 16.7 \\
\hline Lepidium sp. & - & - & 0.5 & 16.7 & - & - \\
\hline \multicolumn{7}{|l|}{ Summary, vascular plants } \\
\hline Total live vascular cover & 9.3 & & 24.3 & & 16.8 & \\
\hline Total native cover & 4.8 & & 4.6 & & 3.1 & \\
\hline Total exotic cover & 4.5 & & 19.8 & & 13.8 & \\
\hline Relative native cover & 48.6 & & 23.3 & & 20.0 & \\
\hline Relative exotic cover & 51.4 & & 76.7 & & 80.0 & \\
\hline Total richness & 11 & & 9 & & 12 & \\
\hline Native richness & 7 & & 6 & & 8 & \\
\hline Exotic richness & 4 & & 3 & & 4 & \\
\hline \multicolumn{7}{|l|}{ Soil-surface features } \\
\hline Rabbit Dung (freq only) & & 91.7 & & 50.0 & & 75.0 \\
\hline Litter & 4.0 & 100.0 & 35.8 & 100.0 & 17.8 & 100.0 \\
\hline Woody debris & - & - & - & - & - & - \\
\hline Gravel (< 75 mm) & 4.2 & 100.0 & 15.8 & 100.0 & 12.2 & 100.0 \\
\hline Cobbles $(75-250 \mathrm{~mm})$ & 1.5 & 66.7 & 5.3 & 100.0 & 5.2 & 100.0 \\
\hline Stones (250 - $600 \mathrm{~mm})$ & 0.5 & 8.3 & 2.8 & 25.0 & 0.6 & 8.3 \\
\hline Total Rock & 6.2 & 100.0 & 23.8 & 100.0 & 17.9 & 100.0 \\
\hline Cyanobacterial crust & - & - & - & - & - & - \\
\hline Lichen crust & - & - & - & - & 0.1 & 8.3 \\
\hline Moss crust & - & - & 0.4 & 41.7 & 0.2 & 8.3 \\
\hline Physical crust & 83.3 & 100.0 & 30.4 & 91.7 & 55.0 & 100.0 \\
\hline Loose, unstable soil & 3.1 & 75.0 & 0.4 & 8.3 & 1.2 & 41.7 \\
\hline Piping (freq only) & & 33.3 & & 8.3 & & 41.7 \\
\hline $\begin{array}{l}\text { Density by height class } \\
\text { Astragalus ampullarioides }\end{array}$ & Count & Per $\mathrm{m}^{2}$ & Count & Per $\mathrm{m}^{2}$ & Count & Per $\mathrm{m}^{2}$ \\
\hline $0.1-4 \mathrm{~cm}$ & 15 & 1.3 & - & - & 6 & 0.2 \\
\hline $5-12 \mathrm{~cm}$ & 3 & 0.3 & - & - & 7 & 0.2 \\
\hline$>12 \mathrm{~cm}$ & - & - & - & - & 1 & 0.0 \\
\hline$>12 \mathrm{~cm}$, flowering & - & - & - & - & 2 & 0.1 \\
\hline Total & 18 & 1.5 & - & - & 16 & 0.5 \\
\hline
\end{tabular}


Table C5. Mean cover, frequency, and density data for Harrisburg soil-vegetation plots.

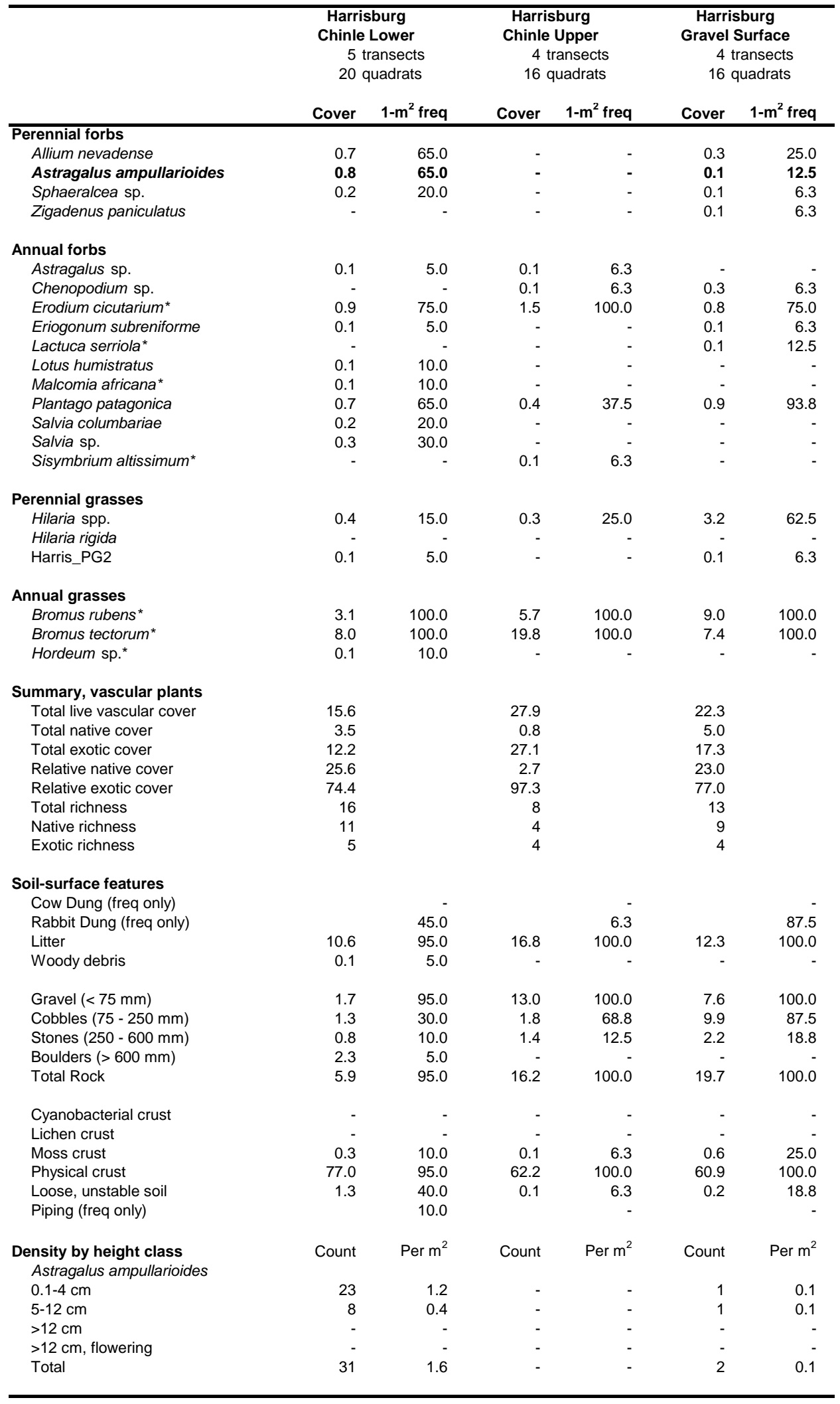


Table C6. Mean cover, frequency, and density data for Pahcoon and Shivwits soil-vegetation plots.

\begin{tabular}{|c|c|c|c|c|c|c|c|c|}
\hline & \multicolumn{2}{|c|}{$\begin{array}{l}\text { Pahcoon } \\
\text { East } \\
3 \text { transects } \\
15 \text { quadrats }\end{array}$} & \multicolumn{2}{|c|}{$\begin{array}{l}\text { Pahcoon } \\
\text { West } \\
3 \text { transects } \\
12 \text { quadrats }\end{array}$} & \multicolumn{2}{|c|}{$\begin{array}{l}\text { Shivwits } \\
\text { Chinle } \\
2 \text { transects } \\
16 \text { quadrats }\end{array}$} & \multicolumn{2}{|c|}{$\begin{array}{l}\text { Shivwits } \\
\text { Moenave } \\
4 \text { transects } \\
12 \text { quadrats }\end{array}$} \\
\hline & Cover & $1-m^{2}$ freq & Cover & $1-m^{2}$ freq & Cover & $1-m^{2}$ freq & Cover & $1-m^{2}$ freq \\
\hline \multicolumn{9}{|l|}{$\overline{\text { Perennial forbs }}$} \\
\hline Astragalus ampullarioides & 2.0 & 80.0 & - & - & 0.1 & 12.5 & 0.3 & 25.0 \\
\hline Chamaesyce albomarginata & 0.4 & 40.0 & - & - & 0.6 & 43.8 & 0.2 & 8.3 \\
\hline Cymopterus purpureus & 0.3 & 26.7 & 0.4 & 41.7 & - & - & - & - \\
\hline Sphaeralcea sp. & - & - & 0.3 & 25.0 & 0.1 & 6.3 & - & - \\
\hline \multicolumn{9}{|l|}{ Annual forbs } \\
\hline Chenopodium sp. & - & - & 0.1 & 8.3 & - & - & - & - \\
\hline Erodium cicutarium* & 0.1 & 6.7 & - & - & 0.1 & 6.3 & - & - \\
\hline Eriogonum subreniforme & 0.1 & 13.3 & 0.1 & 8.3 & 0.3 & 25.0 & 0.6 & 58.3 \\
\hline Euphorbia spathulata & - & - & - & - & - & - & - & - \\
\hline Helianthus sp. & 0.5 & 46.7 & 0.9 & 91.7 & - & - & - & - \\
\hline Lactuca serriola* & 0.2 & 20.0 & 0.1 & 8.3 & 0.1 & 6.3 & - & - \\
\hline Lotus humistratus & 1.7 & 100.0 & 0.9 & 91.7 & 0.1 & 12.5 & - & - \\
\hline Pahcoon_AF2 & 0.1 & 6.7 & - & - & - & - & - & - \\
\hline \multicolumn{9}{|l|}{ Perennial grasses } \\
\hline Elymus elymoides & - & - & 0.3 & 25.0 & - & - & - & - \\
\hline \multicolumn{9}{|l|}{ Annual grasses } \\
\hline Bromus rubens* & 3.7 & 100.0 & 11.7 & 100.0 & 6.3 & 100.0 & 3.8 & 100.0 \\
\hline Bromus tectorum* & 3.1 & 100.0 & 2.2 & 100.0 & 3.3 & 100.0 & 1.2 & 100.0 \\
\hline Bromus, standing dead & 1.5 & 86.7 & 6.3 & & 4.2 & 93.8 & 2.8 & 100.0 \\
\hline \multicolumn{9}{|l|}{ Shrubs / subshrubs } \\
\hline Chrysothamnus viscidiflorus & - & - & - & - & 0.1 & 6.3 & - & - \\
\hline Gutierrezia microcephala & - & - & - & - & - & - & 0.6 & 25.0 \\
\hline Gutierrezia sarothrae & 0.5 & 46.7 & 1.0 & 91.7 & 0.4 & 12.5 & - & - \\
\hline Lepidium fremontii & - & - & - & - & - & - & 0.8 & 16.7 \\
\hline Lycium andersonii & 1.0 & 6.7 & - & - & - & - & - & - \\
\hline Lycium pallidum & 0.1 & 6.7 & - & - & - & - & - & - \\
\hline Psorothamnus fremontii & - & - & - & - & - & - & 0.2 & 16.7 \\
\hline \multicolumn{9}{|l|}{ Trees } \\
\hline Juniperus osteosperma & 0.2 & 6.7 & - & - & - & - & 1.7 & 8.3 \\
\hline \multicolumn{9}{|l|}{ Summary, vascular plants } \\
\hline Total live vascular cover & 13.9 & & 17.8 & & 11.4 & & 9.2 & \\
\hline Total native cover & 6.9 & & 3.9 & & 1.7 & & 4.3 & \\
\hline Total exotic cover & 7.1 & & 13.9 & & 9.7 & & 4.9 & \\
\hline Relative native cover & 50.6 & & 28.6 & & 16.6 & & 31.0 & \\
\hline Relative exotic cover & 49.4 & & 71.4 & & 83.4 & & 69.0 & \\
\hline Total richness & 15 & & 11 & & 11 & & 9 & \\
\hline Native richness & 11 & & 8 & & 7 & & 7 & \\
\hline Exotic richness & 4 & & 3 & & 4 & & 2 & \\
\hline \multicolumn{9}{|l|}{ Soil-surface features } \\
\hline Cow Dung (freq only) & & - & & 8.3 & & - & & - \\
\hline Rabbit Dung (freq only) & & 20.0 & & 41.7 & & 62.5 & & 66.7 \\
\hline Litter & 6.6 & 100.0 & 19.5 & 100.0 & 10.9 & 100.0 & 7.0 & 100.0 \\
\hline Woody debris & 0.4 & 40.0 & 0.5 & 33.3 & 0.4 & 18.8 & 0.1 & 8.3 \\
\hline Gravel $(<75 \mathrm{~mm})$ & 10.6 & 100.0 & 1.0 & 100.0 & 13.4 & 100.0 & 1.0 & 100.0 \\
\hline Cobbles $(75-250 \mathrm{~mm})$ & 0.6 & 40.0 & 0.2 & 8.3 & 0.6 & 18.8 & - & - \\
\hline Total Rock & 11.2 & 100.0 & 1.2 & 100.0 & 14.1 & 100.0 & 1.0 & 100.0 \\
\hline Cyanobacterial crust & - & - & - & - & - & - & - & - \\
\hline Lichen crust & - & - & - & - & - & - & - & - \\
\hline Moss crust & - & - & - & - & - & - & - & - \\
\hline Physical crust & 71.7 & 100.0 & 68.8 & 100.0 & 47.5 & 100.0 & 84.6 & 100.0 \\
\hline Loose, unstable soil & 1.9 & 33.3 & 2.2 & 75.0 & 21.3 & 87.5 & 2.5 & 83.3 \\
\hline Piping (freq only) & & 13.3 & & 50.0 & & 6.3 & & 16.7 \\
\hline $\begin{array}{l}\text { Density by height class } \\
\text { Astragalus ampullarioides }\end{array}$ & Count & Per $\mathrm{m}^{2}$ & Count & Per $\mathrm{m}^{2}$ & Count & Per $\mathrm{m}^{2}$ & Count & Per $\mathrm{m}^{2}$ \\
\hline $0.1-4 \mathrm{~cm}$ & 106 & 7.1 & - & - & 2 & 0.1 & 3 & 0.3 \\
\hline $5-12 \mathrm{~cm}$ & 125 & 8.3 & - & - & 7 & 0.4 & - & - \\
\hline$>12 \mathrm{~cm}$ & - & - & - & - & - & - & 3 & 0.3 \\
\hline$>12 \mathrm{~cm}$, flowering & 8 & 0.5 & - & - & - & - & - & - \\
\hline Total & 239 & 15.9 & - & - & 9 & 0.6 & 6 & 0.5 \\
\hline
\end{tabular}


Appendix D - All Soil-Vegetation Plots in Relation to Soil Texture Classes 


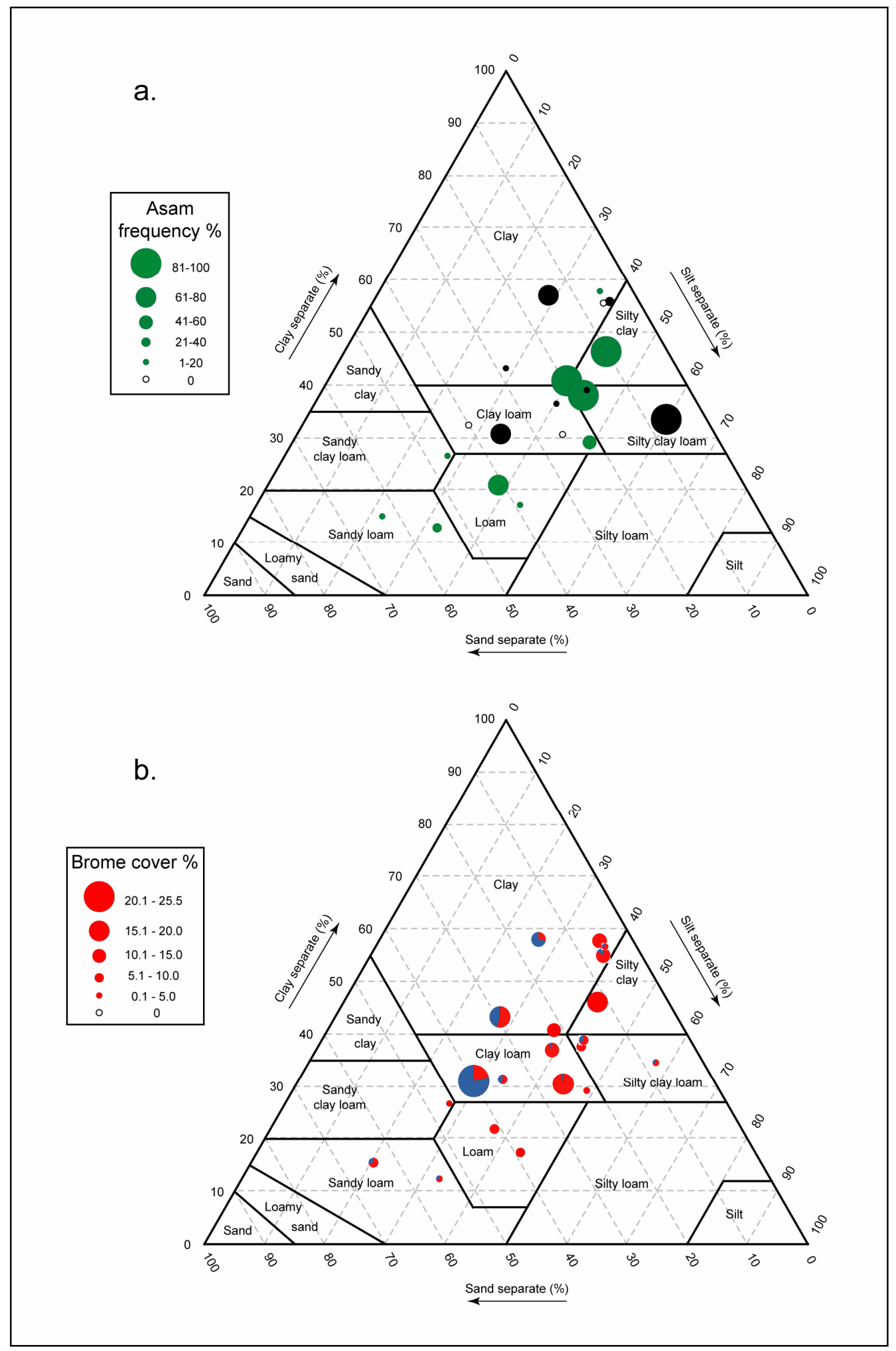

Figure D1. Ordination of 20 soil-vegetation plots in relation to $0-10 \mathrm{~cm}$ soil texture classes. In (a), point size is scaled by milk-vetch (Asam) frequency. Green points indicate plots in Zion NP; black points indicate plots outside the Park. In (b), points sizes are scaled by total cover of exotic brome grasses, with the relative proportions of red brome and cheatgrass cover indicated by red and blue segments, respectively. 